\title{
A novel single-cavity three-wavelength photoacoustic spectrometer for atmospheric aerosol research
}

\author{
Claudia Linke $^{1}$, Inas Ibrahim ${ }^{1}$, Nina Schleicher ${ }^{2}$, Regina Hitzenberger $^{3}$, Meinrat O. Andreae ${ }^{4}$, Thomas Leisner ${ }^{1}$, and \\ Martin Schnaiter ${ }^{1}$ \\ ${ }^{1}$ Institute of Meteorology and Climate Research, Atmospheric Aerosol Research, KIT, Karlsruhe, Germany \\ ${ }^{2}$ Institute of Geography and Geoecology, KIT, Karlsruhe, Germany \\ ${ }^{3}$ University of Vienna, Faculty of Physics, Vienna, Austria \\ ${ }^{4}$ Biogeochemistry Department, Max Planck Institute for Chemistry, Mainz, Germany \\ Correspondence to: Claudia Linke (claudia.linke@kit.edu)
}

Received: 8 March 2016 - Published in Atmos. Meas. Tech. Discuss.: 15 March 2016

Revised: 20 September 2016 - Accepted: 3 October 2016 - Published: 7 November 2016

\begin{abstract}
The spectral light-absorbing behavior of carbonaceous aerosols varies depending on the chemical composition and structure of the particles. A new single-cavity threewavelength photoacoustic spectrometer was developed and characterized for measuring absorption coefficients at three wavelengths across the visible spectral range. In laboratory studies, several types of soot with different organic content were generated by a diffusion flame burner and were investigated for changes in mass-specific absorption cross section (MAC) values, absorption and scattering Ångström exponents $\left(\alpha_{\mathrm{abs}}\right.$ and $\left.\alpha_{\mathrm{sca}}\right)$, and single scattering albedo $(\omega)$. By increasing the organic carbonaceous (OC) content of the aerosol from 50 to $90 \%$ of the total carbonaceous mass, for $660 \mathrm{~nm}$ nearly no change of MAC was found with increasing OC content. In contrast, for $532 \mathrm{~nm}$ a significant increase, and for $445 \mathrm{~nm}$ a strong increase of MAC was found with increasing OC content of the aerosol. Depending on the OC content, the Ångström exponents of absorption and scattering as well as the single scattering albedo increased. These laboratory results were compared to a field study at a trafficdominated urban site, which was also influenced by residential wood combustion. For this site a daily average value of $\alpha_{\mathrm{abs}}(445-660)$ of 1.9 was found.
\end{abstract}

\section{Introduction}

Carbonaceous particulate matter is a unique component of the atmospheric aerosol because of its absorption ability and large chemical variability (IPCC, 2013). Its presence in the atmosphere causes direct and indirect climatic effects. The ability to absorb and scatter sunlight over a wide spectral range directly affects Earth's radiative balance. Indirectly, the presence of aerosol particles influences the lifetime of clouds and their precipitation properties (Rosenfeld et al., 2008; Sun et al., 2007).

In climate modeling, carbonaceous aerosols are represented as black carbon (BC) and organic carbon (OC; ICCP, 2013). In contrast to $B C$, which is a strongly light-absorbing material, most models assume OC to be a nonabsorbing material (Kameel et al., 2014; Andreae and Ramanathan, 2013; Chung et al., 2012). Based on these assumptions, BC contributes by a rather strong positive forcing and $\mathrm{OC}$ by a negative forcing to the overall radiative forcing by carbonaceous aerosols, which is then estimated to be close to zero (IPCC, 2013).

While BC is of deep black appearance, there are further carbonaceous compounds that contribute to atmospheric aerosol absorption. Humic-like substances (HULIS) or brown carbon (brC) are of yellow or brownish color. Even though these compounds are only weak absorbers in comparison to $\mathrm{BC}$, their steeply increasing light absorption towards the ultraviolet (UV) spectrum, and their atmospheric abundance might result in a significant contribution to the short- 
wave absorption by aerosols in the atmosphere (Kirchstetter et al., 2012; Chakrabarty et al., 2010; Hoffer et al., 2006; Andreae and Gelencsér, 2006).

The formation of absorbing organic aerosol particles can occur through different pathways. Chemical and photochemical processes as well as coagulation and oligomerization potentially end up in macromolecular structures. Such chemical systems will form multiple conjugated double and aromatic bonds as well as polyfunctional groups, which build light-absorbing chromophoric structures. These chromophoric structures are responsible for the wavelengthdependent light absorption by organic species in the visible (VIS) and near-UV spectral range (Rincón et al., 2009; Prévôt et al., 2009; Gelencsér et al., 2002).

The transition from volatile organic carbon (VOC) to semivolatile (SVOC), low volatile (LVOC), and extremely low volatile (ELVOC) carbon is continuous. Saleh et al. (2014) showed that for biomass burning emissions, an increase in light absorptivity is linked to a decrease in volatility of the organic compounds.

Emissions from biomass burning and to a large extent from fossil fuel and biofuel combustion contain both black carbon and organic carbon. During burning processes, carbonaceous aerosols are generated by incomplete combustion of these fuels. The chemical composition of the resulting particles is strongly dependent on the combustion conditions (Andreae and Gelencsér, 2006). Particularly, biomass and wood burning is often performed at low temperatures, resulting in high emissions of light-absorbing particulate matter (Kirchstetter et al., 2004; Sandradewi et al., 2008a). Moreover, coemitted primary organic matter of biomass burning emissions might be weakly absorbing or even nonabsorbing, but it enhances the absorbing properties when forming an internal mixture with BC. Therefore, the spectral light absorption properties of such internally mixed carbonaceous particles may be shifted toward the UV wavelength range (Lack et al., 2012).

Considering the diversity of possible sources for carbonaceous particulate matter in the atmosphere, which covers the whole range from biogenic emissions over wildfires to residential heating, it is clear that the contribution of carbonaceous material to climate forcing on a global scale still remains difficult to estimate (Kirchstetter et al., 2012; Bond et al., 2013; Andreae and Ramanathan, 2013).

For BC, the imaginary part of the refractive index is nearly wavelength-independent over the visible and near-UV spectral range. In contrast, the imaginary part of the refractive index of brown carbon (brC) continuously increases from the red over the blue to at least the near-UV spectral range. (Moosmüller et al., 2009; Schnaiter et al., 2006). The small size of the particles and their spectral refractive index induce a wavelength dependence of the aerosol absorption coefficient, which is characterized by the absorption Ångström exponent, $\alpha_{\mathrm{abs}}$. While, in the case of BC, the absorption coefficient is only slightly increasing with decreasing wavelength, which results in $\alpha_{\text {abs }}$ close to 1.0 (Lewis et al., 2008; Kirchstetter et al., 2004; Schnaiter et al., 2003), brC can have a significantly higher absorption coefficient in the blue and nearUV spectral range, resulting in an $\alpha_{\text {abs }}$ higher than 1. From laboratory (McMeeking et al., 2014; Schnaiter et al., 2006) and field studies (Kirchstetter and Thatcher, 2012; Rizzo et al., 2011; Sandradevi et al., 2008a), there is evidence that for brC, the $\alpha_{\mathrm{abs}}$ is much larger than 1.0.

McMeeking et al. (2014) reported values for the absorption Ångström exponent $\alpha_{\text {abs }}$ between 1.5 and 7 from laboratory biomass burning experiments using a variety of different fuels. For carbon particles generated in a diffusion flame under different burning conditions, Schnaiter et al. (2006) determined $\alpha_{\text {abs }}$ values in the range of 1 to 7 .

Kirchstetter and Thatcher (2012) sampled particulate matter during wintertime in a rural region in California, where residential heating was mainly done by wood burning. From their samples, which they collected during evening and nighttime, they derived $\alpha_{\text {abs }}$ values between 3.0 and 7.4. Sandradevi et al. (2008a) investigated the spectral aerosol absorption in a small village in Switzerland, where the majority of the households also used wood burning for heating in winter. For this village, they found values for $\alpha_{\mathrm{abs}}$ of 1.81.9. Nakayama et al. (2014) showed temporal variations for $\alpha_{\mathrm{abs}}$ between summer and winter of 1.21 and 1.43, respectively, for the city of Nagoya, Japan. For measurements in the Amazon basin during the dry season, Rizzo et al. (2011) reported $\alpha_{\text {abs }}$ values between 1.5 and 2.5 resulting from lightabsorbing organic carbon released from biomass burning.

Despite their significance, the light absorption properties of carbonaceous aerosol are poorly investigated, mostly due to lack of appropriate instrumentation (Schmid et al., 2006). Considering the organic mass fraction, which is the dominating component of carbonaceous aerosol in the atmosphere, even a small contribution of organic matter to light absorption may result in a significant absorption of solar radiation (Kirchstetter and Thatcher, 2012; Hoffer et al., 2006).

For in situ absorption measurements, different kinds of instruments are used. Most in situ measurements are performed using filter-based methods, where the aerosol particles are deposited on a filter. This works well for strongly absorbing aerosols. For aerosols with higher organic content and, therefore, with stronger scattering properties, filter-based absorption methods raise experimental uncertainties (Lack et al., 2008; Schnaiter et al., 2005; Weingartner et al., 2003; Bond et al., 1999; Hitzenberger, 1993).

The deposition of the aerosol on a filter may change the physical properties of the particles and the combined optical properties of the deposit and filter substrate (Collaud Coen et al., 2010; Lack et al., 2008). Additionally, filter-based methods require various corrections for multiple scattering on the filter substrate, for backscattering from the deposited particles, and for the reduction of scattering with increasing particle load (Chow et al., 2009). This leads to large uncertainties, especially for atmospheric measurements where the aerosol 


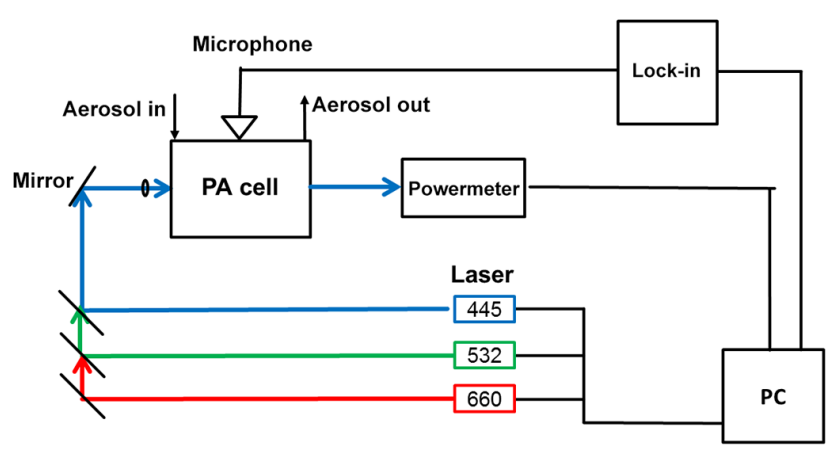

Figure 1. Setup of the three-wavelength photoacoustic spectrometer.

optical properties are dominated by scattering. Under these conditions, an accurate absorption measurement using filterbased methods is limited by the strong cross-sensitivity of the method to the aerosol light scattering.

Unlike these filter-based instruments, the photoacoustic method directly determines the light absorption of aerosol particles in the airborne state. Due to the fact that the photoacoustic method is specific to the absorption properties of the particles there is no cross-sensitivity to particle light scattering, which makes this method ideally suited for atmospheric measurements (Rosencwaig, 1975; Miklós et al., 2001). However, despite these advantages of a direct absorption measurement, during field applications the presence of ambient trace gases, like $\mathrm{NO}_{2}$, ozone, or water vapor can influence the photoacoustic measurement (Arnott et al., 1999). Especially the impact of high relative humidities on the photoacoustic measurement has to be considered (Arnott et al., 2003; Raspet et al., 2003).

In this study, we present a novel single-cavity photoacoustic spectrometer that measures the absorption coefficient of atmospheric aerosols at three wavelengths in the visible spectral range. In Sect. 2, we describe the instrument setup and discuss the instrument characterization in terms of laser power stability, linearity of the electronic setup, and detection limit together with calibration results. A laboratory study is presented in Sect. 3, where combustion emissions from a propane flame were used as surrogates for atmospheric combustion particles with different organic content. Finally, the instrument was applied in an urban field study in Karlsruhe, Germany. The wavelength-dependent absorption properties measured in this study are presented in Sect. 4. The laboratory and field studies have shown a reliable application of the novel photoacoustic spectrometer for ambient aerosol measurements.

\section{Instrument setup}

The absorption measurement by the photoacoustic method is initiated by a modulated laser. Due to the absorption of light by the particles within the laser beam, the carbonaceous material gets energetically excited and, consequently, heats up. The deposited thermal energy is subsequently released into the surrounding gas. Due to the periodic thermal expansion caused by the laser modulation, a pressure or sound wave is generated in the gas. This sound wave is amplified in an acoustic resonator and is detected by a microphone. The acoustic resonator and the microphone form the so-called photoacoustic cell (Rosencwaig, 1975). The photoacoustic signal, PA, generated by the photoacoustic cell, can be expressed as follows:

$\mathrm{PA}=b_{\text {abs }} \times P_{\text {laser }} \times c_{\text {cell }}$.

According to Eq. (1), PA (V) at the resonance frequency of the cell is determined by the aerosol light absorption coefficient $b_{\mathrm{abs}}\left(\mathrm{m}^{-1}\right)$, the laser power $P_{\text {laser }}(\mathrm{W})$, and a cell constant $c_{\text {cell }}\left(\mathrm{VW}^{-1} \mathrm{~m}\right)$.

The cell constant $c_{\text {cell }}$ is a function of the overall geometric setup of the laser, the microphone, and the resonance cell (Miklós et al., 2001). The value of $c_{\text {cell }}$ must be determined by calibrating the system with a material of known absorption cross section.

The setup of the newly developed photoacoustic instrument is shown in Fig. 1. Three-wavelength light absorption and heating of the sample in the photoacoustic cell is induced by three successively irradiating laser beams. Three diode laser modules (Qioptiq Nano 250 series), emitting at 445,532 , and $660 \mathrm{~nm}$, are tuned to the resonance frequency of the cell. During operation, the laser powers are 150, 100, and $50 \mathrm{~mW}$, respectively. The three laser beams are merged with the optical axis of the photoacoustic cell by beam splitters (DLMP 425, DLMP 505, Thorlabs). The laser power is continuously monitored by a power meter (PowerMax, Coherent) at the exit of the resonance cell. The photoacoustic cell was manufactured by HiLase Ltd., Hungary, according to our specifications, and was modified by replacing the original windows by windows with specific broadband anti-reflection coatings. A resonance frequency of $1930 \mathrm{~Hz}$ was determined for the cell at a temperature of $25^{\circ} \mathrm{C}$. The actual acoustic resonator is a pipe with open ends, with a length of $90 \mathrm{~mm}$, a diameter of $8.5 \mathrm{~mm}$, and a volume of $5.1 \mathrm{~cm}^{3}$. The length of the pipe corresponds to $\lambda / 2$ of the resonance frequency of the cell. With these geometric specifications, the pipe works as an open acoustic resonator for the generation of longitudinal acoustic modes. Acoustic buffers are implemented on both sides of the resonator, each with a length of $\lambda / 4$ and a diameter of $60 \mathrm{~mm}$, resulting in a buffer volume of about $130 \mathrm{~cm}^{3}$. The length of the buffers and the sharp enlargement of the diameter between the resonator pipe and the buffer volume ensure (i) optimal back reflection of sound from inside the acoustic resonator, and (ii) resonance frequency filtering of noise from outside the resonator by destructive interference in the buffers. The buffers are terminated by optical windows, which seal the cell against the surrounding gas. Windows with broadband anti-reflection coatings are used to minimize 


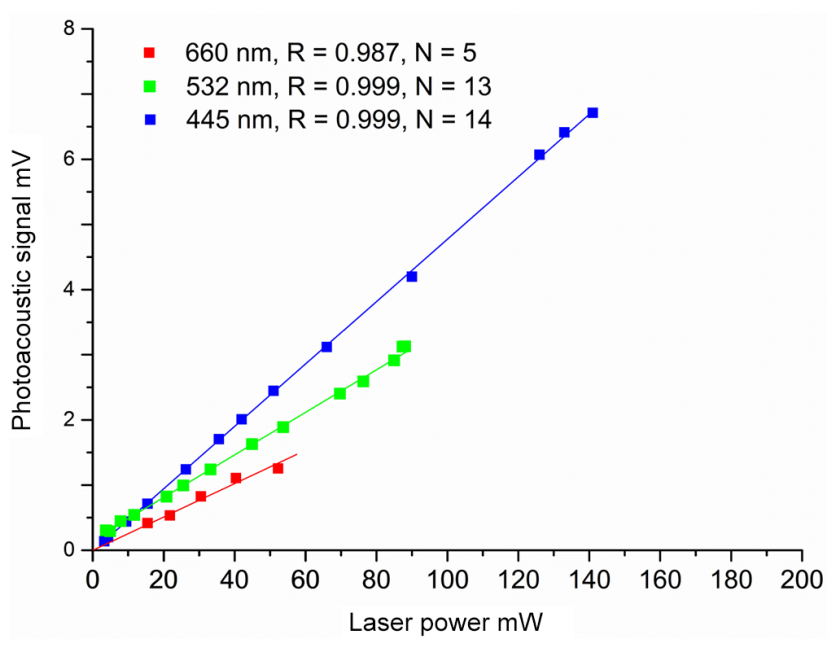

Figure 2. Test of the linearity response of the photoacoustic detection system with laser power.

residual reflections of the laser beam when entering and exiting the resonance cell.

The aerosol enters and exits the cell through the buffers, which results in a $90^{\circ}$ bend in the aerosol flow at the transition points from the buffer volumes to the acoustic resonator. A continuous aerosol flow of 1 std. liter per minute through the cell is maintained by a mass flow controller (Mykrolis, Tylon 2900 series). At this flow rate, the calculated cell volume of about $265 \mathrm{~cm}^{3}$ is exchanged around three to four times a minute. Additionally, $\lambda / 4$ notch filters are installed in line of the aerosol tube, to prevent flow noise from entering the resonator. The calculated aerosol transmission efficiency through the cell including the acoustic notch filters is $97 \%$ for particles with a size of $1 \mu \mathrm{m}$ and a density of $1.8 \mathrm{~g} \mathrm{~cm}^{-3}$.

The microphone is connected to the resonator pipe through a small hole of $5 \mathrm{~mm}$ diameter close to the amplitude node of the fundamental acoustic mode of the cell, i.e., at the center of the pipe. In this way, the photoacoustically generated wave is detected with high sensitivity by a commercial hearing aid microphone (EK-3029, Knowles). This specific microphone was chosen for effective signal detection at resonance frequencies above $1000 \mathrm{~Hz}$.

The microphone signal is fed to a lock-in amplifier (LIABVD-150-L, Femto). This lock-in amplifier is a two-phase instrument, for phase sensitive detection, which provides signal $X$, magnitude $R$, and phase-shift $Y$ with respect to the phase of the incident laser modulation frequency. Suitable lock-in parameters for the amplification and filter characteristics can be set for the input and output amplifier. The signalto-noise ratio can be optimized by an additional low pass filter with adjustable time constant.

To determine the absorption by the aerosol particles, periodic background measurements are performed by passing the aerosol through a particle filter, which effectively removes the particles. The complete exchange of the gas in the cell

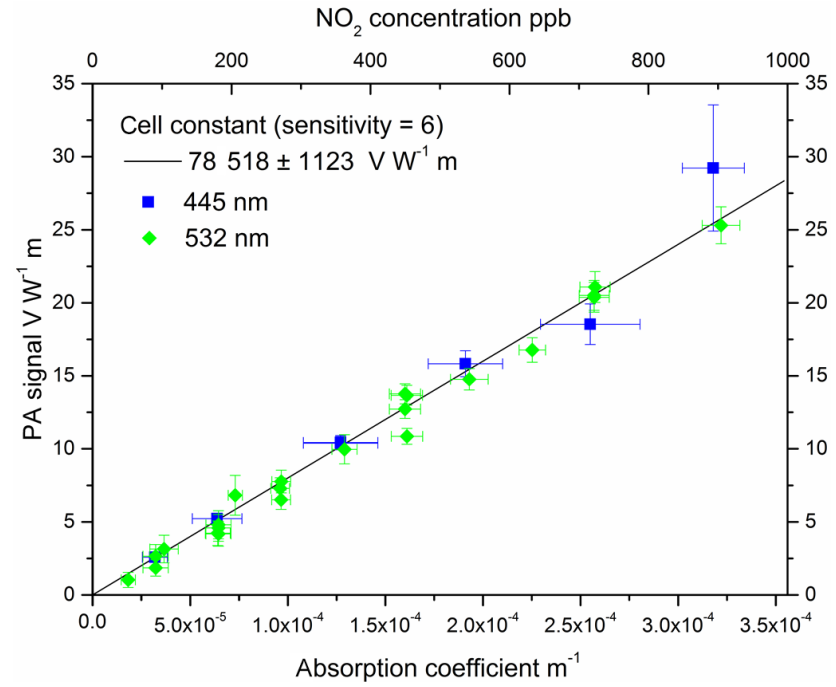

Figure 3. Cell constant determined for the lock-in sensitivity 6 from calibration measurement with $\mathrm{NO}_{2}$ at 445 and $532 \mathrm{~nm}$. Note that some of the $532 \mathrm{~nm}$ measurements were performed at sensitivity 7 and were subsequently rescaled to sensitivity 6 .

volume between the background and aerosol measurements defines the minimum time that is required for the absorption measurement.

From Eq. (1) it is obvious that for accurate measurements a reliable control of the laser power during electronic recording is essential. The laser power stability for an operation period of $8 \mathrm{~h}$ at room temperature was tested and showed maximum deviations from the specified power of less than $2 \%$ for all lasers. In detail, at $445 \mathrm{~nm}$ a laser power stability of $152 \mathrm{~mW} \pm 0.2 \mathrm{~mW}$, at $532 \mathrm{~nm}$ of $105 \mathrm{~mW} \pm 0.4 \mathrm{~mW}$, and at $660 \mathrm{~nm}$ of $52 \mathrm{~mW} \pm 0.6 \mathrm{~mW}$ was found over this operation period. The linearity of the electronic detection and amplification system was checked by gradually decreasing the laser power, while the cell was continuously flushed with nitrogen dioxide $\left(\mathrm{NO}_{2}\right)$ gas $(10 \mathrm{ppm}$, Air Liquide). Figure 2 shows the result for the 445,532 , and $660 \mathrm{~nm}$ wavelengths. The tested power range was up to $150 \mathrm{~mW}$ for $445 \mathrm{~nm}, 100 \mathrm{~mW}$ for $532 \mathrm{~nm}$, and $50 \mathrm{~mW}$ for $660 \mathrm{~nm}$. The power measurements for the three lasers exhibit different slopes for each wavelength. This is attributed to the wavelength-dependent absorption coefficient of $\mathrm{NO}_{2}$, resulting in specific photoacoustic signals, which increase from 660 to $445 \mathrm{~nm}$ as shown in Fig. 2. Furthermore, the photoacoustic response behavior shows high linearity with laser power for all three laser wavelengths. However, variations in the laser power during longterm measurements can directly affect the photoacoustic signal. These errors are reduced by simultaneously measuring the photoacoustic signal and the laser power.

The instrument setup has to be calibrated by a substance of known absorption cross section to determine the correlation between a given absorption coefficient and the measured photoacoustic signal in order to specify the cell con- 


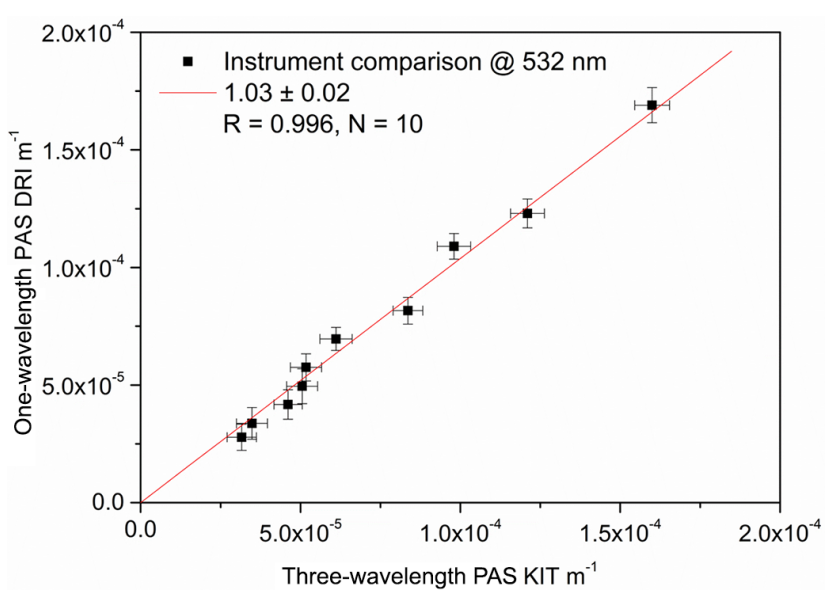

Figure 4. Comparison of two photoacoustic instruments (DRI, PAS KIT) for CAST soot C / O 0.29 at $532 \mathrm{~nm}$.

stant of the setup (cf. Eq. 1). For this purpose, light-absorbing nitrogen dioxide $\left(\mathrm{NO}_{2}\right)$ was used as calibration gas. $\mathrm{Ab}-$ sorption cross sections for nitrogen dioxide are published by Voigt et al. (2002) over a broad wavelength range and for $293 \mathrm{~K}$ and $1000 \mathrm{mbar}$ temperature and total pressure, respectively. The derived absorption cross sections of $\mathrm{NO}_{2}$ are $1.65 \times 10^{-6}$ for $445 \mathrm{~nm}, 3.56 \times 10^{-7}$ for $532 \mathrm{~nm}$, and $1.75 \times 10^{-8} \mathrm{~m}^{-1} \mathrm{ppb}^{-1}$ for $660 \mathrm{~nm}$. The measuring range of the lock-in amplifier can be regulated by adjustment of the gain settings. To determine cell constants at different gains, certified gas mixtures of $\mathrm{NO}_{2}$ in synthetic air (Crystal-Mix, Air Liquide) of 5, 1, or $0.2 \mathrm{ppm}$ were used. Based on the certified gas mixtures, different $\mathrm{NO}_{2}$ gas concentrations are generated by diluting and mixing $\mathrm{NO}_{2}$ standards with synthetic air. For each gain setting a distinct cell constant is determined.

In this study, the cell constants for the amplifier gain settings, i.e., lock-in sensitivities 6 and 7, were determined. In Fig. 3, the cell constant for the lock-in sensitivity 6 of $78518 \pm 1123 \mathrm{~V} \mathrm{~W}^{-1} \mathrm{~m}$ is derived from calibration measurements at 532 (green squares) and $445 \mathrm{~nm}$ (blue squares). The concentrations of the deployed $\mathrm{NO}_{2}$ calibration gas mixtures, indicated at the top axis of Fig. 3, vary from 80 up

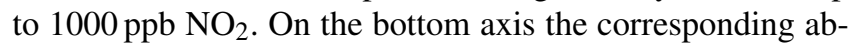
sorption coefficients for $\mathrm{NO}_{2}$ are plotted, calculated from the absorption cross sections for $\mathrm{NO}_{2}$ (Voigt et al., 2002). The cell constant is then calculated from the correlation slope between photoacoustic signal, laser power, and absorption coefficient according to Eq. (1). For the calibration at $532 \mathrm{~nm}$, about one-third of the measurements were originally done at sensitivity 7 and were subsequently rescaled to sensitivity 6 by applying the gain specifications given by the manufacturer.

We compared our novel three-wavelength instrument with a $532 \mathrm{~nm}$ photoacoustic instrument of the Max Planck Institute for Chemistry, Mainz, Germany, which had been orig- inally developed by Desert Research Institute, Reno, USA (Arnott et al., 1999). In Fig. 4, absorption coefficients at $532 \mathrm{~nm}$ measured with both instruments are compared for an aerosol chamber experiment with $\mathrm{BC}$ aerosol from the Combustion Aerosol Standard (CAST) generator (see Sect. 3 for details on the CAST generator and the chamber experiments).

During the experiment both instruments measured absorption coefficients between $2 \times 10^{-5}$ and $1.7 \times 10^{-4} \mathrm{~m}^{-1}$. The slope of the regression line is $1.03 \pm 0.02$, and the coefficient of determination, $R^{2}=0.98$, indicates good agreement of both instruments at $532 \mathrm{~nm}$ over the measured range. Given that two different instruments with different laser and detection systems were compared, this is a very convincing result.

During the laboratory chamber studies the RH was always below $30 \%$. During field measurements there was a silica gel dryer installed upstream of the PA and nephelometer sampling line, which confined the RH to below $60 \%$ throughout the campaign.

The limit of detection (LOD) of the photoacoustic instrument was determined from 4 different days of field measurements by analyzing 10 background (particle-free ambient air) measurements for each wavelength. The LOD was then calculated according to the German standard DIN 32645:

$\mathrm{LOD}=\overline{b_{a}^{\mathrm{BG}}}+3 \times \sigma^{\mathrm{BG}}$,

with $b^{\mathrm{BG}}$ the mean background absorption coefficient and $\sigma^{\mathrm{BG}}$ the corresponding standard deviation. LOD values of $5.6 \times 10^{-6}, 6.6 \times 10^{-6}$, and $1.8 \times 10^{-5} \mathrm{~m}^{-1}$ were deduced for the wavelengths 445,532 , and $660 \mathrm{~nm}$, respectively.

\section{Laboratory studies on CAST soot of different C / O fuel ratios}

Two sets of experiments were performed at the aerosol and cloud chamber facility AIDA. One set was conducted during the SOOT11 campaign in 2010. The second set of experiments was done during the SOOT15 campaign in June 2013. While the SOOT11 campaign took place at the $84 \mathrm{~m}^{3}$ sized AIDA chamber (Wagner et al., 2009) SOOT15 was performed at the smaller stainless steel chamber NAUA with a volume of $3.7 \mathrm{~m}^{3}$ (Schnaiter et al., 2006; Linke et al., 2006).

Before each experiment, the chamber was evacuated, flushed, and refilled with particle-free synthetic air. Combustion Aerosol Standard (CAST) aerosol, generated by a co-flow diffusion burner (miniCAST Series 5200, Jing Ltd., Switzerland), was filled into the clean chamber. The miniCAST generator is a compact version of the first instrument series that had been used in the soot absorption study by Schnaiter et al. (2006). Further details on the operation of the burner together with a characterization of the particle emission can be found there. Note that due to mechanical design changes, the composition characteristics of the emitted particles found by Schnaiter et al. (2006) changed 


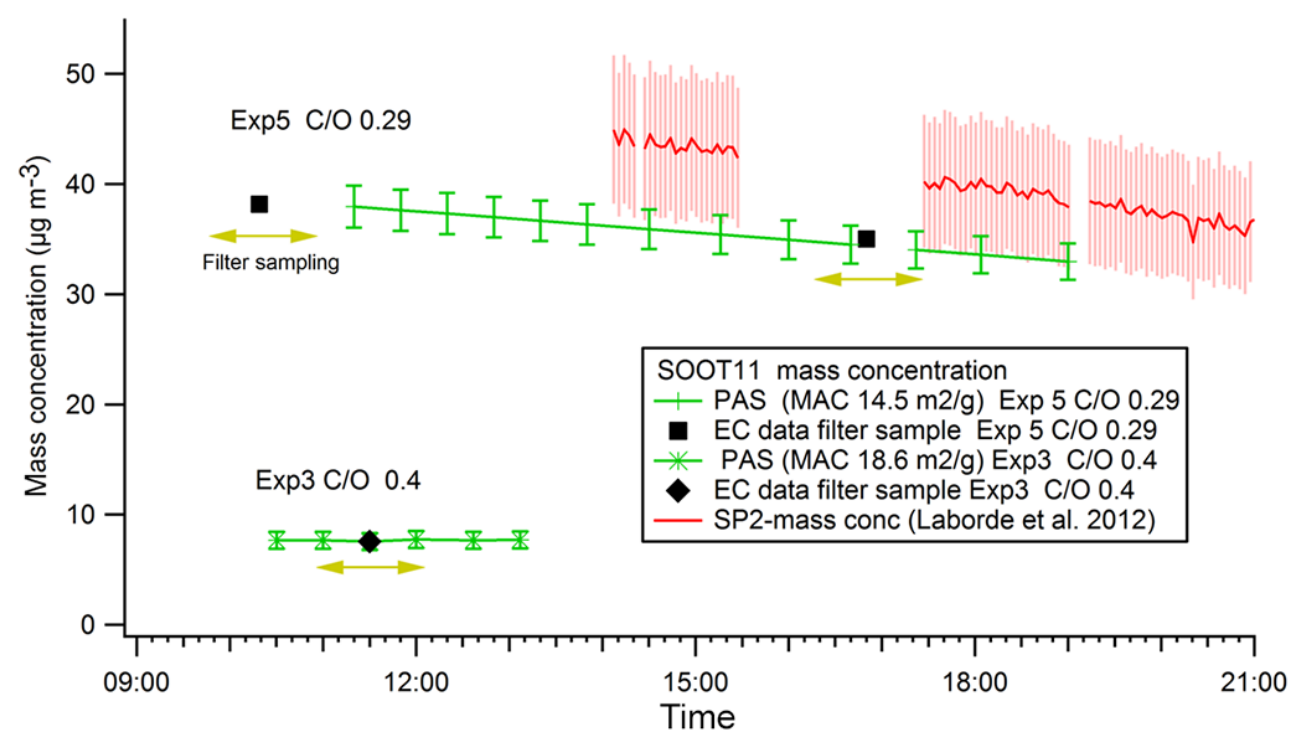

Figure 5. Comparison of mass concentrations determined for two experiments in the SOOT11 campaign by SP-2, filter sampling, and $1-\lambda$-PAS at $532 \mathrm{~nm}$ measurements.

for the miniCAST version. After the aerosol addition to the NAUA chamber, the aerosol was continuously stirred by a mixing fan to ensure homogeneous gas and particle conditions throughout the chamber volume. Stainless steel tubes of $6 \mathrm{~mm}$ diameter were used for aerosol sampling. The aerosol flow through the connected photoacoustic instruments, an integrating nephelometer (TSI, model 3563), and a condensation particle counter (CPC; TSI, model 3022A) was 1, 5, and $1.5 \mathrm{~L} \mathrm{~min}^{-1}$, respectively.

The miniCAST burner was operated with a mixture of propane and synthetic air. Different mass ratios of fuel to air were adjusted to operate the burner at different burning conditions. In this way, the ratio of elemental carbon (EC) to organic carbon (OC) of the generated carbonaceous aerosol could be altered over a broad range (Schnaiter et al., 2006). At low $\mathrm{C} / \mathrm{O}$ ratios the fraction of $\mathrm{EC}$ is dominating in the aerosol generated by the burner. When the $\mathrm{C} / \mathrm{O}$ ratios increase, the fraction of EC is reduced while the OC content of the generated aerosol increases. In our studies the EC content varied between 10 and $50 \%$ of the total carbon (TC) mass.

The TC, EC, and OC concentrations of the aerosol samples were determined from thermal analyses of particle-laden quartz fiber filters. For the filter sampling, $47 \mathrm{~mm}$ diameter quartz fiber filters (Munktell MK360) were inserted into a stainless steel filter holder (Sartorius) and connected directly to the aerosol chamber. With the aid of a mass flow controller with a set flow of $10 \mathrm{std}$. $\mathrm{L} \mathrm{min}^{-1}$, a defined volume of aerosol was sampled from the chamber through the filter. TC, EC, and OC analysis of the particle-laden filters were performed using a Sunset OC / EC thermal analyzer (Sunset Laboratory Inc., USA), applying the EUSAAR-2 temperature protocol (Cavalli et al., 2010). During the thermo-optical measurement, the filter medium is first heated stepwise to $600^{\circ} \mathrm{C}$ in an inert helium atmosphere to desorb OC, then cooled to $500^{\circ} \mathrm{C}$, and reheated in several temperature steps to $800^{\circ} \mathrm{C}$ under a helium/oxygen atmosphere to oxidize EC. To correct for pyrolysis of OC in the inert atmosphere, which would lead to a positive EC artifact, a laser signal is used as optical control to determine the OC-EC split.

The mass concentration of refractory black carbon ( $\mathrm{rBC})$ in the carbonaceous aerosol was determined by a single particle soot photometer SP-2 (DMT, USA). The SP-2 utilizes incandescence of single $\mathrm{rBC}$ particles in a laser cavity to quantify the particle mass down to the sub-femtogram level. The incandescence signal of the instrument was calibrated with size-selected fullerene soot particles (Alfa Aesar). For analysis of the SP-2 data we used the software toolkit developed by Martin Gysel from the Paul Scherrer Institute, Switzerland (http://aerosolsoftware.web.psi.ch/). Details on the instrument characteristics, accuracy, and reproducibility as well as the operation at the AIDA facility were described by Laborde et al. (2012).

\subsection{Photoacoustic measurements during the SOOT11 campaign}

During the SOOT11 campaign, miniCAST experiments with two different $\mathrm{C} / \mathrm{O}$ fuel ratios were performed. One experiment was done with a $\mathrm{C} / \mathrm{O}$ ratio of 0.29 , which corresponds to an $\mathrm{OC} / \mathrm{TC}$ ratio of about $60 \%$, and the second experiment was conducted at a $\mathrm{C} / \mathrm{O}$ ratio of 0.4 , corresponding to an OC fraction of about $90 \%$. At the beginning and the end of each experiment, filter samples were taken for offline OC / EC analysis. Figure 5 shows mass concentrations for both experiments determined by SP-2, filter sampling, and $1-\lambda$-PAS measurements at $532 \mathrm{~nm}$. Details of the instrumen- 
Table 1. Comparison of MAC determined at 532nm during two campaigns - the method-specific carbonaceous mass that the MAC is related to is given by the abbreviations EC and TC (Sunset) as well as rBC (SP-2).

\begin{tabular}{|c|c|c|c|c|c|}
\hline \multirow[b]{2}{*}{ CAST soot } & \multicolumn{3}{|c|}{$\begin{array}{c}\text { SOOT } 11 \\
\text { DRI-1- } \lambda \text {-PAS }\end{array}$} & \multicolumn{2}{|c|}{$\begin{array}{c}\text { SOOT } 15 \\
\text { KIT-3- } \lambda \text {-PAS }\end{array}$} \\
\hline & C / O 0.29 & C / O 0.29 & C / O 0.29 & C / O 0.29 & $\mathrm{C} / \mathrm{O} 0.29$ \\
\hline & $\begin{array}{c}\mathrm{m}^{2} \mathrm{~g}^{-1} \\
14.5 \pm 1.6 \\
\text { MAC-EC }\end{array}$ & $\begin{array}{c}\mathrm{m}^{2} \mathrm{~g}^{-1} \\
5.4 \pm 0.8 \\
\text { MAC-TC }\end{array}$ & $\begin{array}{c}\mathrm{m}^{2} \mathrm{~g}^{-1} \\
12.5 \\
\text { MAC-rBC } \\
\text { Laborde et al. (2012) }\end{array}$ & $\begin{array}{c}\mathrm{m}^{2} \mathrm{~g}^{-1} \\
-\end{array}$ & $\begin{array}{c}\mathrm{m}^{2} \mathrm{~g}^{-1} \\
16.4 \pm 0.4 \\
\text { MAC-rBC }\end{array}$ \\
\hline CAST soot & $\begin{array}{c}\mathrm{C} / \mathrm{O} 0.4 \\
18.6 \pm 4.2 \\
\text { MAC-EC }\end{array}$ & $\begin{array}{c}\mathrm{C} / \mathrm{O} 0.4 \\
1.6 \pm 0.1 \\
\text { MAC-TC }\end{array}$ & $\begin{array}{c}\mathrm{C} / \mathrm{O} \\
0.4 \\
-\end{array}$ & $\begin{array}{c}\mathrm{C} / \mathrm{O} \\
-\end{array}$ & $\begin{array}{c}\mathrm{C} / \mathrm{O} 0.4 \\
21.0 \pm 2.5 \\
\text { MAC-rBC }\end{array}$ \\
\hline
\end{tabular}

tal setup are given by Laborde et al. (2012). In SOOT11, only the single-wavelength photoacoustic instrument from the Max Planck Institute for Chemistry was available, which measured the absorption coefficient at $532 \mathrm{~nm}$.

Mass-specific absorption cross section (MAC) values at $532 \mathrm{~nm}$ were deduced from the photoacoustic absorption coefficients in conjunction with the EC values obtained from the thermo-optical analysis. The MAC values (532) found for $\mathrm{C} / \mathrm{O}$ ratios of 0.29 and 0.4 were $14.5 \pm 1.6$ and $18.6 \pm 4.2 \mathrm{~m}^{2} \mathrm{~g}^{-1}$, respectively (Table 1 ).

Alternatively, the MAC (532) can be determined by using the $\mathrm{rBC}$ mass concentrations measured by the SP-2 instrument resulting in a MAC (532) for the $\mathrm{C} / \mathrm{O}$ ratio 0.29 of $12.5 \mathrm{~m}^{2} \mathrm{~g}^{-1}$ (Laborde et al., 2012). It was not possible to determine the corresponding MAC (532) for the $\mathrm{C} / \mathrm{O}$ ratio of 0.4 in the same way as the $\mathrm{BCC}$ concentration during this experiment was too low and the SP-2 did not provide incandescence signals for this aerosol type (Gysel et al., 2012).

\subsection{Photoacoustic measurements during the SOOT15 campaign}

During the SOOT15 campaign, miniCAST soot experiments at four different burning conditions were conducted. The corresponding $\mathrm{C} / \mathrm{O}$ ratios of $0.25,0.29,0.33$, and 0.38 resulted in $\mathrm{OC} / \mathrm{TC}$ ratios of the combustion aerosols between 50 and $90 \%$ (Table 2). At the beginning of each experiment, a filter sample was taken for offline OC / EC analysis. The experimental setup is shown in Fig. 6.

Particle number concentrations were measured (i) directly from the chamber and (ii) after a dilution stage (PALAS, 3xVKL10). High particle number concentrations in the chamber caused strong coagulation of the aerosol during the first part of the experiment. Initial particle number concentrations in the chamber varied between $3 \times 10^{4}$ and $8 \times 10^{4} \mathrm{~cm}^{-3}$.

The particle size distribution was measured with a scanning mobility particle spectrometer (SMPS), composed of a differential mobility analyzer (DMA 3071, TSI) and a condensation particle counter (CPC 3010, TSI). Due to the aerosol preparation and coagulation in the chamber, the median particle sizes measured in these experiments ranged from 80 to $250 \mathrm{~nm}$.

For the optical characterization of the chamber aerosol, the absorption and scattering coefficients were determined with our new three-wavelength photoacoustic spectrometer in combination with a three-wavelength integrating nephelometer (model 3563, TSI). Before the experiments, the nephelometer was calibrated with $\mathrm{CO}_{2}$ and air. Details on nephelometer operation at the AIDA facility, including a discussion of the error corrections, are given by Schnaiter et al. (2005). Both instruments were connected directly to the aerosol chamber. The scattering coefficients were measured continuously. An automated pneumatic valve (Swagelok, Germany) was used upstream of the inlet of the photoacoustic instrument to change between particle and particle-free background measurements in periodic cycles of about $7 \mathrm{~min}$.

\subsection{Optical properties of CAST soot}

From the photoacoustic and integrating nephelometer measurements, spectrally resolved absorption and scattering coefficients $b_{\text {abs }}(\lambda)$ and $b_{\text {sca }}(\lambda)$ were determined, and the following optical parameters were derived:

i. spectrally resolved mass-specific absorption cross section (MAC) values $(\lambda)$;

ii. Ångström exponents of absorption, $\alpha_{\text {abs }}$, and scattering, $\alpha_{\text {sca }}$

iii. wavelength resolved single scattering albedo, $\omega(\lambda)$.

These parameters are summarized in Table 2 for the different miniCAST aerosol types, and are discussed in more detail in the following sections.

\subsection{Specific absorption cross sections}

In this study, time-resolved mass-specific absorption cross section (MAC) values $(\lambda)$ were derived from the concurrent 
Table 2. Optical properties resulting from different C / O ratios of miniCAST soot during SOOT15.

\begin{tabular}{|c|c|c|c|c|c|c|c|c|c|c|}
\hline $\mathrm{C} / \mathrm{O}$ & $\mathrm{OC} / \mathrm{TC}$ & SP-2 & $\begin{array}{r}\text { MAC } \\
445 \mathrm{~nm}\end{array}$ & $\begin{array}{r}\text { MAC } \\
532 \mathrm{~nm}\end{array}$ & $\begin{array}{r}\text { MAC } \\
660 \mathrm{~nm}\end{array}$ & $\omega(450)$ & $\omega(550)$ & $\omega(700)$ & $\alpha_{\mathrm{abs}}$ & $\alpha_{\text {sca }}$ \\
\hline & $\%^{*}$ & $\mu \mathrm{g} \mathrm{m}^{-3}$ & $\mathrm{~m}^{2} \mathrm{~g}^{-1}$ & $\mathrm{~m}^{2} \mathrm{~g}^{-1}$ & $\mathrm{~m}^{2} \mathrm{~g}^{-1}$ & & & & & \\
\hline 0.25 & $50 \pm 2$ & $16 \pm 5$ & $12.5 \pm 1.7$ & $10.4 \pm 2.3$ & $8.0 \pm 3.4$ & $0.18 \pm 0.05$ & $0.12 \pm 0.03$ & $0.12 \pm 0.06$ & $1.7 \pm 0.5$ & $2.3 \pm 0.06$ \\
\hline 0.29 & $62 \pm 8$ & $34 \pm 1$ & $14.1 \pm 0.9$ & $16.4 \pm 0.4$ & $9.1 \pm 0.8$ & $0.19 \pm 0.01$ & $0.13 \pm 0.01$ & $0.13 \pm 0.01$ & $1.3 \pm 0.2$ & $2.2 \pm 0.02$ \\
\hline 0.33 & FF & $29 \pm 18$ & $19.0 \pm 2.9$ & $17.7 \pm 3.0$ & $9.9 \pm 3.1$ & $0.32 \pm 0.03$ & $0.21 \pm 0.04$ & $0.21 \pm 0.03$ & $1.5 \pm 0.2$ & $2.3 \pm 0.1$ \\
\hline 0.38 & $89 \pm 2$ & $3 \pm 0.4$ & $31 \pm 5.9$ & $21 \pm 2.5$ & $9.4 \pm 2.9$ & $0.38 \pm 0.04$ & $0.19 \pm 0.04$ & $0.27 \pm 0.07$ & $3.1 \pm 1.0$ & $3.4 \pm 0.1$ \\
\hline
\end{tabular}

* Filter samples were taken before optical measurement. FF: incorrect filter sampling.

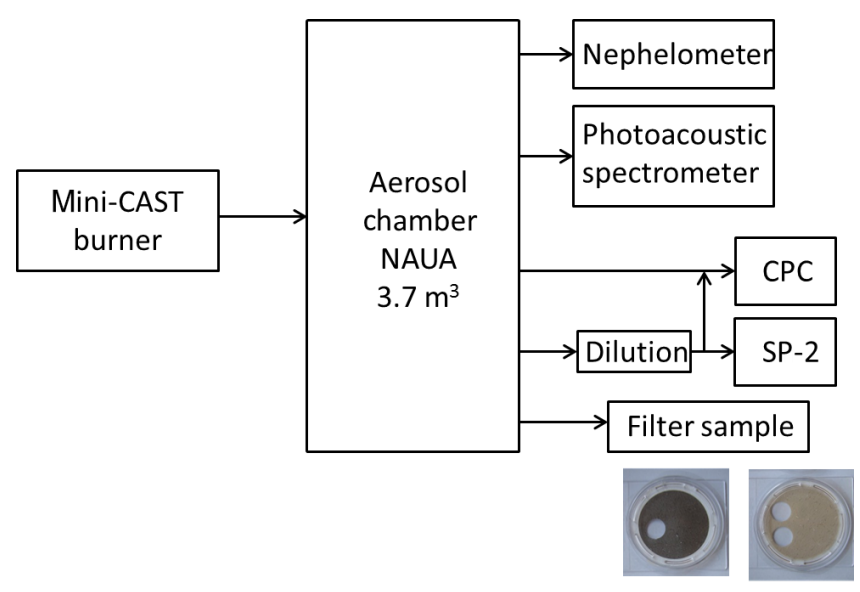

Figure 6. Setup of instruments during the laboratory study SOOT15 and filter samples of CAST soot C/O 0.29 (left) and C / O 0.38 (right).

measurements of the photoacoustic absorption coefficients and the rBC mass from the SP-2. The filter sampling for EC / OC analysis could only be done at the beginning of each experiment to determine the OC / TC fraction of the aerosol at each $\mathrm{C} / \mathrm{O}$ ratio of the miniCAST. In order to avoid perturbation of the aerosol sampling during the optical measurements, no filter sampling was possible in parallel with the experiments; therefore no comparisons of BC mass from SP2 to EC mass from filter measurements are available for the SOOT15 experiments.

With increasing $\mathrm{C} / \mathrm{O}$ fuel ratio in the flame of the miniCAST generator, the organic content of the emitted carbonaceous aerosol rises. The $\mathrm{OC}$ fraction in the total carbon aerosol mass at $\mathrm{C} / \mathrm{O}$ ratio of 0.25 is about $50 \%$ and increases towards higher $\mathrm{C} / \mathrm{O}$ ratio up to $90 \%$ or more.

The color of the aerosol filter samples taken from the chamber already indicated a change in the optical behavior of the emitted aerosol. While the quartz filters were deep black at $\mathrm{C} / \mathrm{O}$ ratios of 0.25 and 0.29 , the filter sample at 0.38 was of brownish appearance (Fig. 6).

The MAC at $660 \mathrm{~nm}$, which was the longest wavelength measured here, remained almost constant with increasing organic content of the aerosol (Table 2). In contrast, the MAC

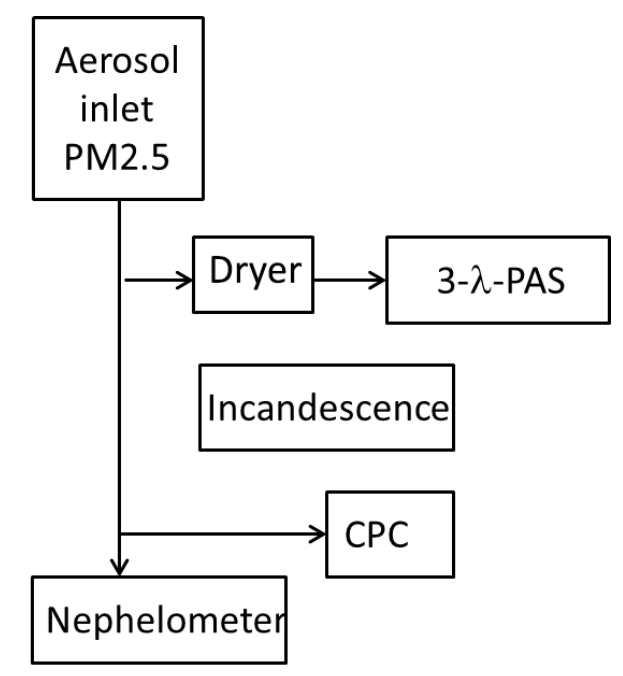

Figure 7. Setup of instruments during field study.

at $532 \mathrm{~nm}$ clearly increased with increasing $\mathrm{C} / \mathrm{O}$ ratio from $10.4 \pm 2.3$ to $21.0 \pm 2.5 \mathrm{~m}^{2} \mathrm{~g}^{-1}$. An even stronger functional dependence was observed for the MAC determined for the shortest investigated wavelength of $445 \mathrm{~nm}$. For this wavelength, the MAC increased from $12.5 \pm 1.7 \mathrm{~m}^{2} \mathrm{~g}^{-1}$ at a C / O ratio of 0.25 to $31.0 \pm 5.9 \mathrm{~m}^{2} \mathrm{~g}^{-1}$ at a $\mathrm{C} / \mathrm{O}$ ratio of 0.38 . Here, the MAC(445 nm) of the carbonaceous aerosol with a OC content of about $90 \%$ was 2.5 times higher than the corresponding MAC value of the aerosol with an OC content of only $50 \%$. As the MAC in this case is based on the SP-2 rBC mass measurement, this result clearly shows that the OC material that was co-emitted with the $\mathrm{BC}$ must have a nonnegligible absorption cross section with a strong wavelength dependence.

The results of the SOOT15 campaign were in agreement with the results of the SOOT11 study, where the absorption coefficients as well as the carbonaceous content of the samples were determined with partly different instrumentation at $\mathrm{C} / \mathrm{O}$ ratios of 0.29 and 0.4 , but only at $532 \mathrm{~nm}$.

In SOOT15, the determined value of the MAC (532) at a $\mathrm{C} / \mathrm{O}$ ratio of 0.29 was $16.4 \pm 0.4 \mathrm{~m}^{2} \mathrm{~g}^{-1}$ (Table 2). This fits quite well with measurements done during the SOOT11 campaign, where we determined a MAC (532) 


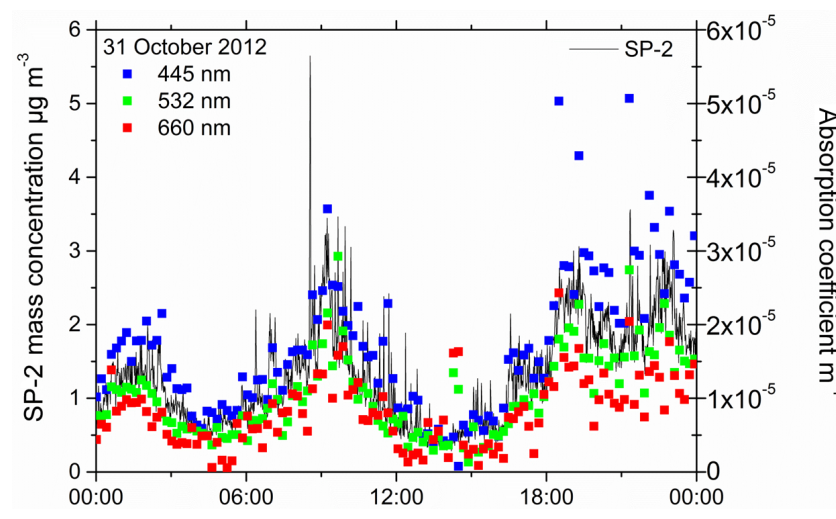

Figure 8. SP-2 incandescence mass concentrations (black line) and photoacoustic absorption coefficients (blue, green, red squares) for 1 day in fall 2012, Karlsruhe, Germany.

of $14.5 \pm 1.6 \mathrm{~m}^{2} \mathrm{~g}^{-1}$ with the $1 \lambda$-PAS (DRI) and thermooptical EC (Table 1). When comparing the MAC (532) value for $\mathrm{C} / \mathrm{O} 0.29$ of SOOT15 with the corresponding MAC (532) value of $12.5 \mathrm{~m}^{2} \mathrm{~g}^{-1}$ from SOOT11 that was based on the SP-2 incandescence measurement (Laborde et al., 2012), both values agree within a range of about $30 \%$. Due to the high organic carbon content of around $90 \%$, the CAST aerosol produced at a $\mathrm{C} / \mathrm{O}$ ratio of 0.38 in SOOT15 should be comparable to the corresponding aerosol in SOOT11, which was produced at a $\mathrm{C} / \mathrm{O}$ ratio of 0.4. For SOOT15 we derived a MAC (532) value of $21.0 \pm 2.5 \mathrm{~m}^{2} \mathrm{~g}^{-1}$ for this aerosol type. For SOOT11 the corresponding value was $18.6 \pm 4.2 \mathrm{~m}^{2} \mathrm{~g}^{-1}$. Both values again agree nicely, given the fact that they were measured with different instruments. A reliable SP-2 incandescence measurement at these high $\mathrm{C} / \mathrm{O}$ ratios was found to be impossible, and for this reason no rBC mass-specific absorption cross section could be specified.

\section{5 Ångström exponents}

The Ångström exponents of the absorption and scattering coefficients were deduced by fitting a power law function to the three measured coefficients:

$\log b_{\mathrm{abs}, \mathrm{sca}}(\lambda 2)=\alpha_{\mathrm{abs}, \mathrm{sca}} \times \log (\lambda 2 / \lambda 1)+\log b_{\mathrm{abs}, \mathrm{sca}}(\lambda 1)$.

Carbonaceous material with $\alpha_{\text {abs }}$ of unity only shows a slight spectral behavior as described for BC in the UV-VIS spectral wavelength range by Schnaiter et al. (2003) and Moosmüller (2009). For the miniCAST burner, a fuel-to-air ratio with $\mathrm{C} / \mathrm{O}$ of 0.29 is close to the conditions for the stoichiometric combustion. For this $\mathrm{C} / \mathrm{O}$ ratio, we derived the lowest values for the Ångström exponents $\alpha_{\text {abs }}$ and $\alpha_{\text {sca }}$ of $1.3 \pm 0.2$ and $2.2 \pm 0.02$, respectively (Table 2 ). The $\alpha_{\text {abs }}$ value of 1.3 is rather low and represents a weak wavelength dependence. With increasing organic content in the soot samples, both Ångström exponents clearly increase, reflecting a steeper wavelength dependence of both coefficients, $b_{\mathrm{abs}}(\lambda)$ and $b_{\text {sca }}(\lambda)$. At a $\mathrm{C} / \mathrm{O}$ ratio of 0.38 with an organic content of almost $90 \%$, the Ångström exponent $\alpha_{\text {abs }}$ reached $3.1 \pm 1.0$, while $\alpha_{\text {sca }}$ increased to $3.4 \pm 0.1$.

\subsection{Single scattering albedo}

The single scattering albedo $\omega$ is defined as the ratio of the light scattering coefficient to the extinction coefficient, i.e., the sum of the scattering and absorption coefficients. $\omega\left(\lambda_{s}\right)$ was deduced from the measured scattering and absorption coefficients at the wavelength positions $\lambda_{s}$ of the integrating nephelometer. For that, the absorption Ångström exponents $\alpha_{\text {abs }}$ of Table 2 were used to inter- and extrapolate the photoacoustic absorption coefficients measured at 445,532 , and $660 \mathrm{~nm}$ to absorption coefficients at the nephelometer wavelengths, i.e., at 450,550 , and $700 \mathrm{~nm}$.

After adjusting the absorption coefficients to the corresponding nephelometer wavelengths the single scattering albedo of the aerosol at 450,550 , and $700 \mathrm{~nm}$ was calculated and is presented in Table 2 .

The single scattering albedo $\omega(\lambda)$ increases with increasing $\mathrm{C} / \mathrm{O}$ ratio of the carbonaceous aerosol.

\subsection{Discussion of the chamber results}

In the chamber experiments presented, we determined MAC values of combustion aerosols with increasing organic content. It is important to note that the CAST propane diffusion flame generator was used as a reproducible source for a combustion aerosol analog. By changing the fuel-to-oxygen ratio, the influence of incomplete combustion - manifested by increasing organic carbon (OC) content - on the absorbing properties of the soot aerosol could be systematically investigated. However, combustion OC material does not necessarily represent all atmospheric OC compounds as most of the latter material stems from secondary processes like the oxidation of volatile organic compounds. This should be kept in mind when comparing our laboratory results with results from field measurements. The $\mathrm{rBC}$ mass measured by the SP-2 incandescence method was compared to the offline elemental carbon (EC) and total carbon (TC) analysis results that were obtained by the thermo-optical method. The experiments show that for aerosols with higher organic content, the MAC of rBC (MAC-rBC) and EC (MAC-EC) increases.

On the other hand, due to the increase in the OC mass, the MAC of TC (MAC-TC) decreases with increasing C / O ratio. Schnaiter et al. (2006) found MAC-TC with the predecessor version of the CAST burner of $5.5 \pm 0.7$ and $3.8 \pm 0.5 \mathrm{~m}^{2} \mathrm{~g}^{-1}$ for combustion aerosol produced with a $\mathrm{C} / \mathrm{O}$ ratio of 0.29 and 0.4 , respectively. Relating the absorption coefficients measured at $532 \mathrm{~nm}$ during SOOT11 to the TC mass concentration, MAC-TC values of $5.4 \pm 0.8$ and $1.6 \pm 0.2 \mathrm{~m}^{2} \mathrm{~g}^{-1}$ are deduced for the $\mathrm{C} / \mathrm{O} 0.29$ and $\mathrm{C} / \mathrm{O}$ 0.4 combustion aerosol, respectively. Comparing the MAC 


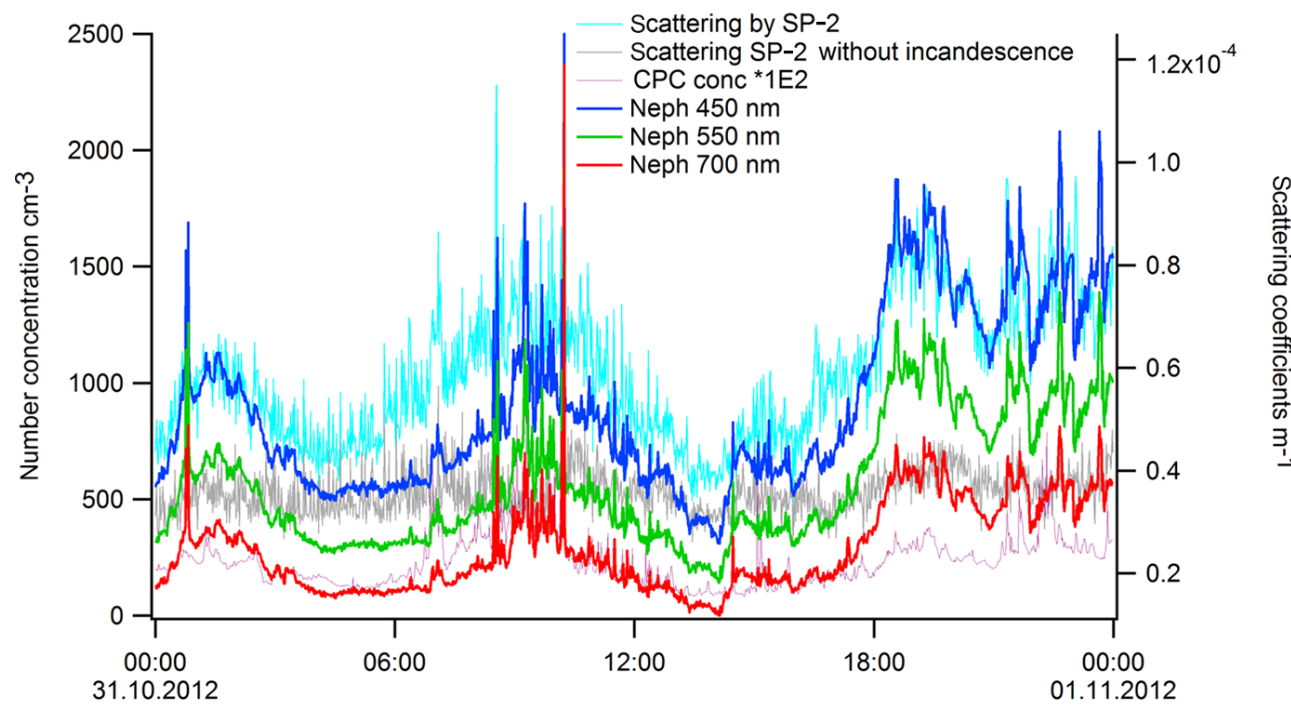

Figure 9. Number concentrations measured by CPC (purple line), SP-2 for all scattering particles (gray line), and scattering particles without incandescence (light blue line) compared to scattering coefficients from the nephelometer at three wavelengths.

from both studies, the values nicely agree for the $\mathrm{C} / \mathrm{O}$ ratio of 0.29 but differ significantly for the $\mathrm{C} / \mathrm{O}$ ratio of 0.4 . The latter discrepancy is due to the fact that different CAST burner models were used. Schnaiter et al. (2006) used the predecessor version of the CAST burner, which significantly differs in the dimensions of the combustion chamber compared to the miniCAST 5200 burner that was used in the SOOT11 and SOOT15 studies. Due to these differences, the flaming conditions in both burner models are different, resulting in different EC / OC vs. C / O characteristics for the emitted combustion aerosol (see a comparison of both burners in Crawford et al., 2011), which limits direct comparisons of the EC / OC ratios of the aerosol emitted for similar C / O ratios. As shown by Crawford et al. (2011), combustion at a $\mathrm{C} / \mathrm{O}$ ratio of 0.4 in the miniCAST model produces aerosol with an EC / OC ratio that corresponds to the aerosol emission for flaming conditions at $\mathrm{C} / \mathrm{O}$ ratios around 0.8 in the predecessor version of the CAST burner. Note that the thermographic analysis of EC, TC, and OC in Schaiter et al. (2006) was done according to the VDI method (Ulrich et al., 1990; Watson et al., 2005).

In a laboratory study by Kirchstetter and Novakov (2007), the MAC values of $\mathrm{BC}$ aerosol generated with a diffusion flame were determined. The generated BC particles, which were analyzed by a thermal optical analysis (TOA) method described by Novakov (1981), contained no significant amounts of OC. Kirchstetter and Novac used a Particle Soot Absorption Photometer (PSAP) to measure the absorption coefficient at a wavelength of $530 \mathrm{~nm}$. This measurement was then related to the "BC" mass of the TOA method, or in this case, because OC was negligible, the EC mass, to deduce a MAC of $8.5 \mathrm{~m}^{2} \mathrm{~g}^{-1}$ for the combustion aerosol. A single scattering albedo, $\omega(550 \mathrm{~nm})$, of 0.15 was determined from the PSAP data and simultaneous measurements of the scattering coefficient with a single-wavelength integrating nephelometer. In our study, the BC aerosol with the lowest $\mathrm{OC}$ content of $50 \%(\mathrm{C} / \mathrm{O}=0.25)$ resulted in a MAC-rBC at $532 \mathrm{~nm}$ of $10.4 \pm 2.3 \mathrm{~m}^{2} \mathrm{~g}^{-1}$ and a $\omega$ at $532 \mathrm{~nm}$ of 0.12 . Comparing both results, it can be concluded that for $532 \mathrm{~nm}$ even a significant increase in the OC content of the aerosol only results in a moderate increase of the MAC. Even though these laboratory studies are not directly comparable to atmospherically processed combustion emissions and, furthermore, different methods were used in the laboratory and field studies, it should be mentioned that comparable MAC values of $\mathrm{BC}$ have also been obtained from atmospheric measurements. Kondo et al. (2009) analyzed ambient aerosols at six rural and urban sites in Asia, which are strongly impacted by vehicle and/or biomass burning emissions. For their measurements they used two different filterbased photometers, a Particle Soot Absorption Photometer (PSAP) and a Continuous Soot Monitoring System (COSMOS). To remove the volatile aerosol components they used a heated inlet system at temperatures of $400^{\circ} \mathrm{C}$ before measuring $\mathrm{BC}$ on the filter. Together with mass measurements (EC / OC analyzer, Sunset Laboratory) they found MAC values at $565 \mathrm{~nm}$ of $10.5 \pm 0.7 \mathrm{~m}^{2} \mathrm{~g}^{-1}$ for the remaining $\mathrm{BC}$ for samples of widely different $\mathrm{BC}$ sources.

The light absorption by organic species increases towards shorter wavelengths. Lewis et al. (2008) investigated the optical properties of different biomass burning aerosols during laboratory measurements in the Fire Laboratory Missoula Experiment (FLAME). For different biomass types, they determined the Ångström exponent, $\alpha_{\text {abs }}$, in the wavelength range covered by their measurements $(405,532$, and $870 \mathrm{~nm}$ ). From these experiments, they found that for sev- 
eral biomass fuels the span of Ångström exponents is greater in the wavelength range between 405 and $870 \mathrm{~nm}$ than between 532 and $870 \mathrm{~nm}$, and concluded that the particle emissions from these fuels absorb near-UV radiation much more efficiently. Similarly, in our measurements the $\alpha_{\mathrm{abs}}$, determined between 445 and $660 \mathrm{~nm}$, increased significantly with increasing organic content of the aerosol (Table 1). While the carbonaceous aerosol with an organic content of about $60 \%$ has a moderate $\alpha_{\text {abs }}$ of 1.3 , the carbonaceous aerosol with almost $90 \%$ organics reaches $\alpha_{\mathrm{abs}}=3.1$. This increase reflects the stronger MAC increase at shorter wavelengths in case of combustion aerosol with a high organic content (Table 1).

To estimate the contribution of brC to the total absorption at $445 \mathrm{~nm}$ for the different $\mathrm{C} / \mathrm{O}$ fuel ratios, we calculated the hypothetical fraction of absorption by $\mathrm{BC}$ at $445 \mathrm{~nm}$ assuming (i) a $\alpha_{\mathrm{abs}}$ of 1.0 for $\mathrm{BC}$ in all four experiments listed in Table 2 and (ii) the MAC-rBC at $660 \mathrm{~nm}$ to be only due to BC. From the difference between the measured MAC-rBC at $445 \mathrm{~nm}$ and MAC-rBC at $445 \mathrm{~nm}$ only calculated for the hypothetical BC fraction, the fraction of absorption by brC in the light-absorbing mass can be estimated. The fraction of absorption by brC during these experiments changes from 5.1 at $\mathrm{C} / \mathrm{O} 0.25$ to $55 \%$ at $\mathrm{C} / \mathrm{O} 0.38$.

\section{Urban field study}

The three-wavelength photoacoustic spectrometer was operated for the first time in the field during a campaign in October/November 2012. The measuring site at Durlacher Tor is a central traffic junction in the urban area of Karlsruhe, Germany. This site is generally characterized by high traffic volume, but at the time of the campaign, intense construction work for a new subway tunnel was taking place.

The measuring site was located next to a three-lane road and close to a street crossing. The aerosol was sampled at a distance of $5 \mathrm{~m}$ from the road and a height of $3 \mathrm{~m}$ above ground using a particulate matter head (PM2.5) (DPM2.5/1/00, Fa.Digitel) with a sampling volume of $1 \mathrm{~m}^{3} \mathrm{~h}^{-1}$. The sampled aerosol was led down to the instruments, which were located beneath the sampling head inside a simple cabin with a power supply connection. The aerosol inlet flow enters the cabin via a $14 \mathrm{~mm}$ diameter stainless steel tubing. Within a flow splitter, 5 and $2.6 \mathrm{~L} \mathrm{~min}^{-1}$ were taken isokinetically from the aerosol inlet flow. From the splitter, $5 \mathrm{~L} \mathrm{~min}^{-1}$ was led through the nephelometer and $2.6 \mathrm{~L} \mathrm{~min}^{-1}$ through the joint flow line for the $3-\lambda$ photoacoustic spectrometer with a sample flow of $1 \mathrm{~L} \mathrm{~min}^{-1}$, the SP-2 with a sample flow of $0.12 \mathrm{~L} \mathrm{~min}^{-1}$, and the CPC (model 3775, TSI) with a sample flow of $1.5 \mathrm{~L} \mathrm{~min}^{-1}$. Upstream of the $3-\lambda$-photoacoustic spectrometer, a diffusion dryer (filled with silica gel) was installed. The setup of the instruments during the campaign is shown in Fig. 7.

Additionally, filter samples were taken with a second sampler unit using a $\mathrm{PM}_{2.5}$ head and a sampling volume
Table 3. Specific absorption cross section (MAC) values determined from photoacoustic, SP-2 incandescence, and thermo-optical measurements for 31 October 2012 (24 h average) at Durlacher Tor, Karlsruhe.

\begin{tabular}{lccc}
\hline$\lambda(\mathrm{nm})$ & 445 & 532 & 660 \\
\hline $\begin{array}{l}\text { MAC }\left(\mathrm{m}^{2} \mathrm{~g}^{-1}\right) \\
(\mathrm{rBC} \mathrm{SP}-2)\end{array}$ & $12.9 \pm 2.8$ & $8.4 \pm 3.1$ & $7.5 \pm 4.9$ \\
$\begin{array}{l}\text { MAC }\left(\mathrm{m}^{2} \mathrm{~g}^{-1}\right) \\
\text { (EC Sunset) }\end{array}$ & $11.6 \pm 6.2$ & $7.7 \pm 3.5$ & $6.9 \pm 2.7$ \\
\hline
\end{tabular}

of $2.3 \mathrm{~m}^{3} \mathrm{~h}^{-1}$ on quartz filters for offline thermo-optical EC / OC analysis. Each day the filter sampling took place for $23.5 \mathrm{~h}$ from 14:00 to 13:30 local time of the next day.

The campaign started on 16 October and ended on 6 November 2012. During the first 2 weeks the weather was sunny, with daytime temperatures around $15^{\circ} \mathrm{C}$ and without any rain. On 27 October, the weather changed considerably from warm and sunny fall weather to cold nights and cold but sunny days, which also initiated the start of the home heating season.

\subsection{Results from the urban field campaign}

Here, we exemplarily show and discuss the measurement results for 31 October. In Fig. 8, the SP-2 mass measurements are shown (black line; left axis) as refractory rBC mass concentration. Furthermore, the absorption coefficients from the photoacoustic measurements are shown for the three instrument wavelengths (blue, green, and red squares; right axis). The figure shows a good correlation between rBC mass concentration and the absorption coefficients. Typical diurnal variations in $\mathrm{rBC}$ mass concentration due to rush hour traffic in the morning and traffic and domestic heating in the evening can be observed.

Figure 9 presents the particle number concentration determined by CPC and the number concentration of scattering particles deduced from the SP-2 measurements (left axis). While the gray line represents the number concentration of all scattering particles, the light blue line only shows the number concentration of those scattering particles that have no incandescence signal, i.e., contain no rBC mass. The scattering coefficients obtained from the nephelometer are shown for the three nephelometer wavelengths (red, green, and blue; right axis). The temporal evolution of the nephelometer data matches the measured number concentration of all scattering particles (gray line), while there is only a weak correlation with the number concentration of $\mathrm{rBC}$-free scattering particles. This clearly indicates that the light scattering coefficient was dominated by particles that are linked to combustion processes (traffic or heating emissions).

We derived MAC-rBC $(\lambda)$ values from the photoacoustic absorption coefficients and SP-2 mass measurements. These values were averaged over a time period of $24 \mathrm{~h}$, starting 
Table 4. Angström exponents of absorption, $\alpha_{\mathrm{abs}}$, derived for 31 October 2012 at Durlacher Tor, Karlsruhe.

\begin{tabular}{lccc}
\hline Range $\lambda 1$ to $\lambda 2$ & $445-532 \mathrm{~nm}$ & $532-660 \mathrm{~nm}$ & $445-660 \mathrm{~nm}$ \\
\hline$\alpha_{\text {abs }}(24 \mathrm{~h}$ ave) & $2.6 \pm 0.8$ & $1.3 \pm 0.6$ & $1.9 \pm 0.6$ \\
$\alpha_{\text {abs }}(20: 00-22: 00)$ & $2.9 \pm 0.9$ & $1.7 \pm 0.5$ & $2.3 \pm 0.4$ \\
\hline
\end{tabular}

at midnight. The absorption coefficients were derived with a time resolution of almost $14 \mathrm{~min}$. The time resolution of the SP-2 incandescence measurement was matched to the time resolution of the photoacoustic measurement. The absorption coefficients were then related to the associated SP-2 $\mathrm{rBC}$ mass concentration in the corresponding time window. Over one $24 \mathrm{~h}$ cycle, about 100 individual values for MAC$\operatorname{rBC}(\lambda)$ were determined. As shown in Table 3, we obtained a MAC-rBC(660) value of $7.5 \pm 4.9 \mathrm{~m}^{2} \mathrm{~g}^{-1}$, a MAC-rBC(532) value of $8.4 \pm 3.1 \mathrm{~m}^{2} \mathrm{~g}^{-1}$, and a MAC-rBC(445) value of $12.9 \pm 2.8 \mathrm{~m}^{2} \mathrm{~g}^{-1}$.

These data can be compared to the $\operatorname{MAC}-\operatorname{EC}(\lambda)$ values derived by relating the photoacoustic measurement to the EC mass concentration determined by the thermooptical method. For this, the absorption coefficients were averaged over the $24 \mathrm{~h}$ time period of the filter sampling and then related to the EC mass concentration obtained from offline filter analysis. We obtained a MAC$\mathrm{EC}(660)$ value of $6.9 \pm 2.7 \mathrm{~m}^{2} \mathrm{~g}^{-1}$, a MAC-EC (532) value of $7.7 \pm 3.5 \mathrm{~m}^{2} \mathrm{~g}^{-1}$, and a MAC-EC (445) value of $11.6 \pm 6.2 \mathrm{~m}^{2} \mathrm{~g}^{-1}$. The $\operatorname{MAC}(\lambda)$ values determined from the SP-2 incandescence and the Sunset thermo-optical analysis are in very good agreement, keeping in mind that two different techniques were used to obtain the $\mathrm{rBC}$ and $\mathrm{EC}$ mass concentrations (Table 3).

To provide evidence that residential wood burning in the evening hours increases the OC fraction in the carbonaceous aerosol and, consequently, increases the shortwave MAC at this urban site, we compared average MAC values for two time windows. For the traffic-dominated period, we chose the time between 07:00 and 09:00 local time. For the period that was likely to be influenced by residential wood burning, we selected the time between 20:00 and 22:00. The MAC values for the traffic-dominated period that we found were MAC-rBC(445) $=10.8 \pm 1.0, \quad$ MAC-rBC $(532)=7.0 \pm 0.8$, and $\mathrm{MAC}-\mathrm{rBC}(660)=5.9 \pm 1.5 \mathrm{~m}^{2} \mathrm{~g}^{-1}$. The averaged MAC values for evening hours were MAC$\operatorname{rBC}(445)=14.8 \pm 4.2, \quad$ MAC-rBC $(532)=8.6 \pm 2.0, \quad$ and MAC-rBC $(660)=6.0 \pm 1.7 \mathrm{~m}^{2} \mathrm{~g}^{-1}$, thus showing a clear increase in MAC in the blue spectral range during the period influenced by residential wood burning.

The Ångström exponents of absorption derived for 31 October are shown in Table 4 . Averaging the measurements over the $24 \mathrm{~h}$ period results in an $\alpha_{\text {abs }}$ value of 1.9 for the 445 to $660 \mathrm{~nm}$ spectral range. When $\alpha_{\text {abs }}$ was specifically calculated for the shortwave range between 445 and $532 \mathrm{~nm}$
Table 5. Single scattering albedo $\omega(\lambda)$ (nephelometer wavelengths) and Scattering Angström Exponents, $\alpha_{\text {sca }}$, derived for 31 October 2012 (24 h average) at Durlacher Tor, Karlsruhe.

\begin{tabular}{cccc}
\hline$\omega(450)$ & $\omega(550)$ & $\omega(700)$ & $\alpha_{\text {sca }} 450-700$ \\
\hline $0.85 \pm 0.3$ & $0.72 \pm 0.2$ & $0.78 \pm 0.3$ & $1.7 \pm 0.2$ \\
\hline
\end{tabular}

and the longwave range between 532 and $660 \mathrm{~nm}$, values for $\alpha_{\text {abs }}(445-532)$ and $\alpha_{\text {abs }}(532-660)$ of 2.6 and 1.3 were derived, respectively.

In Table 5, the single scattering albedo, $\omega(\lambda)$, at the three nephelometer wavelengths, and the scattering Ångström exponent $\alpha_{\text {sca }}$ are given for the measurements at Durlacher Tor. The values for $\omega(\lambda)$ are in the range typical for atmospheric aerosols, but are significantly higher than the values given in Table 2 for the chamber experiments. The value of the scattering Ångström exponent, $\alpha_{\text {sca }}$, is $1.7 \pm 0.2$, and is significantly lower than the corresponding value deduced for all four chamber experiments (Table 2). A possible explanation for these observations is that in contrast to the laboratorygenerated combustion aerosol, the aerosol at Durlacher Tor is likely burdened with additional dust particles such as those released by the large construction area.

\subsection{Comparison of the field results with literature data}

The MAC determined for freshly generated $\mathrm{BC}$ at $550 \mathrm{~nm}$ is in the range of $7.5 \pm 1.2 \mathrm{~m}^{2} \mathrm{~g}^{-1}$ (Bond et al., 2013; Bond and Bergström, 2006). These authors state that the MAC(3) will increase by up to $50 \%$ when the $\mathrm{BC}$ aerosol is internally mixed with other aerosol compounds. For brown carbon, a weak light absorption with a MAC(3) of about $1 \mathrm{~m}^{2} \mathrm{~g}^{-1}$ is usually given in the literature (Bond et al., 2013).

From field studies, a range of different $\operatorname{MAC}(\lambda)$ was published (Kondo et al., 2009; Knox et al., 2009; Laborde et al., 2013; Petzold et al., 2002; Snyder and Schauer, 2007; Thompson et al., 2012). Additionally, different protocols for the EC / OC mass analysis hamper the comparison of MAC values given in the literature. Chan et al. (2011) reported MAC(781) values for rural, suburban, and urban locations in Canada, which differ between 9 and $43 \mathrm{~m}^{2} \mathrm{~g}^{-1}$ when using the NIOSH 5040 protocol and between 6 and $27 \mathrm{~m}^{2} \mathrm{~g}^{-1}$ when using the IMPROVE protocol for the EC / OC mass analysis. In our study, we used the EUSAAR 2 protocol, which was set up to optimize charring corrections and to minimize biases in EC and split point determination (Cavalli et al., 2010).

At $532 \mathrm{~nm}$ we derived MAC(532) values of 8.4 and $7.7 \mathrm{~m}^{2} \mathrm{~g}^{-1}$ when relating to SP-2 and filter-based mass measurements, respectively (Table 3 ). Interpolating these values to $550 \mathrm{~nm}$ (with $\left.\alpha_{\text {abs }}(445-660)=1.9\right)$ results in MAC(3) values of 7.9 and $7.2 \mathrm{~m}^{2} \mathrm{~g}^{-1}$, which is in very good agreement 
with the average value of $7.5 \pm 1.2 \mathrm{~m}^{2} \mathrm{~g}^{-1}$ derived by Bond and Bergström (2006) for freshly emitted BC.

Especially in the blue range of the visible spectrum there are fewer literature data available for the MAC. From biomass burning experiments during FLAME 3, McMeeking et al. (2014) reported an average MAC(405) of $9.8 \pm 1.5 \mathrm{~m}^{2} \mathrm{~g}^{-1}$ determined from combined photoacoustic and single-particle mass spectrometric measurements for heated and unheated aerosol samples with minimal coating.

Healy et al. (2015) reported an average MAC(405) of $8.4 \mathrm{~m}^{2} \mathrm{~g}^{-1}$ for a traffic site in Toronto, Canada, from combined photoacoustic and single-particle mass spectrometric measurements. Ueda et al. (2015) measured soot-containing aerosols at the NOTO site in the city of Suzu, Japan. They reported values of photoacoustic absorption coefficients and SP-2 mass concentrations, which result in MAC(405) values between 11.1 and $15.8 \mathrm{~m}^{2} \mathrm{~g}^{-1}$.

Olson et al. (2015) reported MAC data in the wavelength range between 880 and $370 \mathrm{~nm}$ from various source emissions measured by an aethalometer, a photoacoustic extinctiometer, and thermo-optical EC/OC mass analysis. Three-wavelength absorption was measured for aerosol produced by different fuels including wood, agricultural biomass, coals, plant matter, and petroleum distillates in controlled combustion settings. They reported bulk MAC (660/520/470/370) values for Diesel aerosol of $6.61 / 8.3 / 9.28 / 11.07 \mathrm{~m}^{2} \mathrm{~g}^{-1}$, for wood burning aerosol of $2.66 / 3.34 / 3.73 / 4.52 \mathrm{~m}^{2} \mathrm{~g}^{-1}$, and for pellets burning of $2.69 / 7.15 / 14 / 49.91 \mathrm{~m}^{2} \mathrm{~g}^{-1}$.

For our traffic-dominated, but residential-heatinginfluenced measurements, we found MAC(445) between 11.6 and $12.9 \mathrm{~m}^{2} \mathrm{~g}^{-1}$ (Table 3), which is in the range of the literature data for fresh traffic emissions. Calculating the difference between the determined MAC at $445 \mathrm{~nm}$ of the whole aerosol and the MAC(445) calculated only for BC using an $\alpha_{\mathrm{abs}}$ of 1.0 accounts for the fraction of brC. In this case the calculated absorption fraction of brC is in the range between 11.8 and $13.8 \%$, which indicates that the aerosol absorption was dominated by traffic emissions.

During biomass burning experiments, McMeeking et al. (2014) and Liu et al. (2014) showed that $\alpha_{\text {abs }}$ is strongly related to $\omega(\lambda)$. McMeeking et al., found $\alpha_{\mathrm{abs}}$ of 1.5 to 7 and $\omega(781)$ values of 0.4 to 1.0 . For $\alpha_{\mathrm{abs}}$ around 2 they found $\omega(781)$ below 0.8 , while when $\alpha_{\text {abs }}$ rapidly increases up to 7 , the $\omega(781)$ value approaches 1.0 . These results are in good agreement with our data given in Tables 4 and 5. Chakrabarty et al. (2010) determined $\alpha_{\mathrm{abs}}$ and $\omega(\lambda)$ of tar balls from agricultural biomass combustion of duff. The measurements result in $\alpha_{\text {abs }}(405-532)$ of 6.4 and $\omega(405)$ of $0.95, \omega(532)$ of 0.98 and $\omega(780)$ of 0.98 . As a possible criterion for identifying brC, Chakrabarty et al. (2010) proposed a negative Ångström exponent of $\omega(\lambda)$.

While Schnaiter et al. (2006) reported negative Ångström exponents of $\omega(\lambda)$ for CAST soot experiments at high OC content, neither during our current laboratory study nor at the field measurements were negative Ångström exponents of $\omega(\lambda)$ found.

\section{Conclusions}

For an effective characterization of the optical properties of carbonaceous aerosols, the accurate determination of spectrally resolved absorption coefficients is essential. The discussion of light-absorbing organic species makes a wavelength-dependent determination of the absorption coefficients indispensable. Ideal measurements should cover the whole wavelength range from the near-UV to visible to the near-infrared spectrum.

During chamber and field experiments, our novel singlecavity photoacoustic spectrometer was found to accurately measure spectrally resolved absorption coefficients at three wavelengths. The advantage of a single-cavity instrument is that the cell constant can be successfully determined at different wavelengths.

Different artificially generated carbonaceous aerosols with increasing organic content were investigated. From these measurements, increasing mass-specific absorption cross section (MAC) values were derived towards shorter visible wavelengths. It was shown that the shortwave MAC strongly increases with organic content of the aerosol. This sensitivity to the OC content of the combustion aerosol was also reflected by the single scattering albedo, $\omega(\lambda)$, and the absorption Ångström exponent, $\alpha_{\mathrm{abs}}$, which both increase towards higher organic content of the aerosol.

Comparing the laboratory-deduced MAC values with the values derived for ambient carbonaceous aerosol measured at an urban field site, it became obvious that the aerosol at the site was dominated by traffic emissions. However, a specific investigation of the diurnal variations in the spectral absorption measurements showed that the aerosol was influenced by residential wood burning during the evening hours. These first field results with our photoacoustic spectrometer are encouraging and strengthen the necessity for long-term measurements of the spectral aerosol absorption in urban environments.

\section{Data availability}

All the data presented in this study are available from the authors upon request.

Acknowledgements. This work was funded by the HelmholtzGemeinschaft Deutscher Forschungszentren as part of the program "Atmosphere and Climate" and a start-up budget of the "KIT Kompetenzbereich Erde und Umwelt". The SP-2 and the development of the PAS were funded by the HGF Ausbauinvestition ATMONSYS. We thank the AIDA team and especially Georg Scheurig, Thomasz Chudy, and Steffen Vogt for their technical support. We would like to thank Reiner Gebhardt (IfGG, KIT) who installed the 
cabin and facilities at Durlacher Tor. We gratefully acknowledge Otmar Schmid (formerly Max Planck Institute for Chemistry), Uli Pöschl (Max Planck Institute for Chemistry), and the Max Planck Society for their support.

The article processing charges for this open-access publication were covered by a Research

Centre of the Helmholtz Association.

Edited by: A. Wiedensohler

Reviewed by: three anonymous referees

\section{References}

Andreae, M. O. and Gelencsér, A.: Black carbon or brown carbon? The nature of light-absorbing carbonaceous aerosols, Atmos. Chem. Phys., 6, 3131-3148, doi:10.5194/acp-6-3131-2006, 2006.

Andreae, M. O. and Ramanathan, V.: Climate's dark forcings, Science, 340, 280-281, 2013.

Arnott, W. P., Moosmüller, H., Rogers, C. F., Jin, T., and Bruch, R.: Photoacoustic spectrometer for measuring light absorption by aerosol: instrument description, Atmos. Environ., 33, 28452852, 1999.

Arnott, W. P., Moosmüller, H., Sheridan, P. J., Ogren, J. A. Raspet, R., Slaton, V. W., Hand, J. L., Kreidenweis, S. M., and Collett Jr., J. L.: Photoacoustic and filter-based ambient aerosol light absorption measurements: Instrument comparisons and the role of relative humidity, J. Geophys. Res., 108, 4034-4044, 2003.

Bond, T. C., Anderson, T., and Campbell, D.: Calibration and intercomparison of filter-based measurements of visible light absorption of aerosols, Aerosol Sci. Technol., 30, 582-600, 1999.

Bond, T. C. and Bergstrom, R. W.: Light absorption by carbonaceous particles: An investigative review, Aerosol Sci. Technol., 40, 27-67 2006.

Bond, T. C., Doherty, S. J., Fahey, D. W., Forster, P. M., Berntsen, T., DeAngelo, B. J., Flanner, M. G., Ghan, S., Kärcher, B., Koch, D., Kinne, S., Kondo, Y., Quinn, P. K., Sarofim, M. C., Schultz, M. G., Schulz, M., Venkataraman, C., Zhang, H., Zhang, S., Bellouin, N., Guttikunda, S. K., Hopke, P. K., Jacobson, M. Z., Kaiser, J. W., Klimont Z., Lohmann, U., Schwarz, J. P., Shindell, D., Storelvmo, T., Warren, S. G., and Zender, C. S.: Bounding the role of black carbon on the climate system: A scientific assessment, J. Geophys. Res.-Atmos, 118, 5380-5552, 2013.

Cavalli, F., Viana, M., Yttri, K. E., Genberg, J., and Putaud, J.-P.: Toward a standardised thermal-optical protocol for measuring atmospheric organic and elemental carbon: the EUSAAR protocol, Atmos. Meas. Tech., 3, 79-89, doi:10.5194/amt-3-79-2010, 2010.

Chakrabarty, R. K., Moosmüller, H., Chen, L.-W. A., Lewis, K., Arnott, W. P., Mazzoleni, C., Dubey, M. K., Wold, C. E., Hao, W. M., and Kreidenweis, S. M.: Brown carbon in tar balls from smoldering biomass combustion, Atmos. Chem. Phys., 10, 63636370, doi:10.5194/acp-10-6363-2010, 2010.

Chan, T. W., Brook, J. R., Smallwood, G. J., and Lu, G.: Time-resolved measurements of black carbon light absorption enhancement in urban and near-urban locations of south- ern Ontario, Canada, Atmos. Chem. Phys., 11, 10407-10432, doi:10.5194/acp-11-10407-2011, 2011.

Chow, J. C., Watson, J. G., Doraiswamy, P., Chen, L. A., Sodeman, D. A., Lowenthal, D. H., Park, K., Arnott, W. P., and Motallebi, N.: Aerosol light absorption, black carbon, and elemental carbon at the Fresno Supersite, California, Atmos. Res., 93, 874-887, 2009.

Collaud Coen, M., Weingartner, E., Apituley, A., Ceburnis, D., Fierz-Schmidhauser, R., Flentje, H., Henzing, J. S., Jennings, S. G., Moerman, M., Petzold, A., Schmid, O., and Baltensperger, U.: Minimizing light absorption measurement artifacts of the Aethalometer: evaluation of five correction algorithms, Atmos. Meas. Tech., 3, 457-474, doi:10.5194/amt-3-457-2010, 2010.

Chung, C. E., Ramanathan, V., and Decremer, D.: Observationally constrained estimates of carbonaceous aerosol radiative forcing, P. Natl. Acad. Sci. USA, 109, 11624-11629, doi:10.1073/pnas.1203707109, 2012.

Crawford, I., Möhler, O., Schnaiter, M., Saathoff, H., Liu, D., McMeeking, G., Linke, C., Flynn, M., Bower, K. N., Connolly, P. J., Gallagher, M. W., and Coe, H.: Studies of propane flame soot acting as heterogeneous ice nuclei in conjunction with single particle soot photometer measurements, Atmos. Chem. Phys., 11, 9549-9561, doi:10.5194/acp-11-9549-2011, 2011.

Gelencsér, A., Hoffer, A., Kiss, G., Tombácz, E., Kurdi, R., and Bencze, L.: In situ formation of light absorbing organic matter in cloud water, J. Atmos. Chem., 45, 25-33, 2002.

Gysel, M., Laborde, M., Mensah, A. A., Corbin, J. C., Keller, A., Kim, J., Petzold, A., and Sierau, B.: Technical Note: The single particle soot photometer fails to reliably detect PALAS soot nanoparticles, Atmos. Meas. Tech., 5, 3099-3107, doi:10.5194/amt-5-3099-2012, 2012.

Healy, R. M., Wang, J. M., Jeong, C. H., Lee, A. K. Y., Willis, M. D., Jaroudi, E., Zimmerman, N., Hilker, N., Murphy, M., Eckhardt, S., Stohl, A., Abbatt, J. P. D., Wenger, J. C., and Evans, G. J.: Light absorbing properties of ambient black carbon and brown carbon from fossil fuel and biomass burning sources, J. Geophys. Res.-Atmos., 120, 6619-6633, 2015.

Hitzenberger, R.: Absorption measurements with an integrating plate photometer - calibration and error analysis, Aerosol Sci. Technol. 18, 70-84, 1993.

Hoffer, A., Gelencsér, A., Guyon, P., Kiss, G., Schmid, O., Frank, G. P., Artaxo, P., and Andreae, M. O.: Optical properties of humic-like substances (HULIS) in biomass-burning aerosols, Atmos. Chem. Phys., 6, 3563-3570, doi:10.5194/acp-6-3563-2006, 2006.

IPCC: Report of the WMO, Chapter 7 (clouds and aerosols) and Chapter 8: Anthropogenic and natural radiative forcin, 2013.

Kameel, R., Lee, S. H., Hoffmann, M. R., and Colussi, A. J.: Polarity and oxidation level of visible absorbers in model organic aerosol, Chem. Phys. Lett., 603, 57-61, 2014.

Kirchstetter, T. W. and Novakov, T.: Controlled generation of black carbon particles from a diffusion flame and applications in evaluating black carbon measurement methods, Atmos. Environ., 41, 1874-1888, 2007.

Kirchstetter, T. W. and Thatcher, T. L.: Contribution of organic carbon to wood smoke particulate matter absorption of solar radiation, Atmos. Chem. Phys., 12, 6067-6072, doi:10.5194/acp-126067-2012, 2012. 
Kirchstetter, T. W., Novakov, T., and Hobbs, P. V.: Evidence that spectral light absorption by aerosols emitted from biomass burning and motor vehicles is different due to organic carbon, J. Geophys. Res., 109, D21208, doi:10.1029/2004JD004999, 2004.

Knox, A., Evans, G. J., Brook, J. R., Yao, X., Jeong, C.-H., Godri, K. J., Sabaliauskas, K., and Slowik ,J. G.: Mass Absorption Cross-Section of Ambient Black Carbon Aerosol in Relation to Chemical Age, Aerosol Sci. Technol., 43, 522-532, doi:10.1080/02786820902777207, 2009

Kondo, Y., Sahu, L., Kuwata, M., Miyazaki, Y., Takegawa, N., Moteki, N., Imaru, J., Han, S., Nakayama, T., Kim Oanh, N. T., Hu, M., Kim, Y. J., and Kita, K.: Aerosol. Sci. Technol., 43, 741756, 2009.

Laborde, M., Schnaiter, M., Linke, C., Saathoff, H., Naumann, K.H., Möhler, O., Berlenz, S., Wagner, U., Taylor, J. W., Liu, D., Flynn, M., Allan, J. D., Coe, H., Heimerl, K., Dahlkötter, F., Weinzierl, B., Wollny, A. G., Zanatta, M., Cozic, J., Laj, P., Hitzenberger, R., Schwarz, J. P., and Gysel, M.: Single Particle Soot Photometer intercomparison at the AIDA chamber, Atmos. Meas. Tech., 5, 3077-3097, doi:10.5194/amt-5-3077-2012, 2012.

Laborde, M., Crippa, M., Tritscher, T., Jurányi, Z., Decarlo, P. F., Temime-Roussel, B., Marchand, N., Eckhardt, S., Stohl, A., Baltensperger, U., Prévôt, A. S. H., Weingartner, E., and Gysel, M.: Black carbon physical properties and mixing state in the European megacity Paris, Atmos. Chem. Phys., 13, 5831-5856, doi:10.5194/acp-13-5831-2013, 2013.

Lack, D. A., Richardson, M. S., Law, D., Langridge, L. M., Cappa, C. D., McLaughlin, R. J., and Murphy, D. M.: Aircraft instrument for comprehensive characterization of aerosol optical properties, Part 2: Black and brown carbon absorption and absorption enhancement measured with photoacoustic spectroscopy, Aerosol Sci. Technol., 46, 555-568, 2012.

Lack, D. A., Cappa, C. D., Covert, D. S., Baynard, T., Massoli, T., Sierau, B., Bates, T. S., Quinn, P. K., Lovejoy, E. R., and Ravishankara, A. R.: Bias in Filter-Based Aerosol Light Absorption Measurements Due to Organic Aerosol Loading: Evidence from Ambient Measurements, Aerosol Sci. Technol. 42, 1033-1041, 2008.

Lewis, K., Arnott, W. P., Moosmüller, H., and Wold, C. E.: Strong spectral variations of biomass smoke light absorption and single scattering albedo observed with a novel dualwavelength photoacoustic instrument, J. Geophys. Res., 113, D16203, doi:10.1029/2007JD009699, 2008.

Linke, C., Möhler, O., Veres, A., Mohácsi, Á., Bozóki, Z., Szabó, G., and Schnaiter, M.: Optical properties and mineralogical composition of different Saharan mineral dust samples: a laboratory study, Atmos. Chem. Phys., 6, 3315-3323, doi:10.5194/acp-63315-2006, 2006.

Liu, S., Aiken, A. C., Arata, C., Dubey, M. K., Stockwell, C. E., Yokelson, R. J., Stone, E. A. Jayarathne, T., Robinson, A. L., Demott, P. J., and Kreidenweis, S. M.: Aerosol single scattering albedo dependence on biomass combustion efficiency: Laboratory and field studies, Geophys. Res. Lett., 41, 742-748, doi:10.1002/2013GL058392, 2014.

McMeeking, G. R., Fortner, E., Onasch, T. B. Taylor, J. W., Flynn, M., Coe, H., and Kreidenweis, S. M.: Impacts of nonrefractory material on light absorption by aerosols emitted from biomass burning, J. Geophys. Res.-Atmos., 119, 12272-12286, doi:10.1002/ 2014JD021750, 2014.

Miklós, M., Hess, P., and Bozóki, Z.: Application of acoustic resonators in photoacoustic trace gas analysis and metrology, Rev. Sci. Instrum., 72, 1937-1955, 2001.

Moosmüller, H., Chakrabarty, R. K., and Arnott, W. P.: Aerosol light absorption and its measurement: A review, J. Quant. Spectrosc. Ra., 110, 844-878, 2009.

Nakayama, T., Ikeda, Y., Sawada, Y, Setoguchi, Y., Ogawa, S. Kawana, K, Mochida, M., Ikemori, F., Matsumoto, K., and Matsumi, Y.: Properties of light absorbing aerosol in the Nagoya urban area, Japan, in August 2011 and January 2012: Contributions of brown carbon and lensing effect, J. Geophys. Res.-Atmos., 119, 12721-12739, 2014.

Novakov T.: Microchemical characterization of aerosols, in: Nature, Aim and Methods of Microchemistry, Springer NY, 141-165, 1981.

Olson, M. R., Garcia, M. V., Robinson, M. A., Van Rooy, P., Dietenberger, M. A., Bergin, M., and Schauer, J. J.: Investigation of black and brown carbon multiple wavelength dependent light absorption from biomass and fossil fuel source emissions, J. Geophys. Res.-Atmos., 120, 6682-6697, 2015.

Petzold, A., Kramer, H., and Schönlinner, M.: Continuous measurement of atmospheric black carbon using a multi-angle absorption photometer, Environ. Sci. Pollut. Res., 4, 78-82, 2002.

Prévôt, A. H., DeCarlo, P. F., Lanz, V. A., and Baltensperger, U: Organic aerosol in the atmosphere, PSI Scientific Report, 82-83, 2009.

Raspet, R., Slaton, W. V., Arnott, W. P., and Moosmüller, H.: Evaporation-Condensation effects on resonant photoacoustics of volatile aerosols, J. Atmos. Ocean. Technol., 20, 685-695, 2003.

Rincón, A. G., Guzmán, M. I., Hoffmann, M. R., and Colussi, A. J.: Optical absorptivity versus molecular composition of model organic aerosol matter, J. Phys. Chem. A, 113, 10512-10520, 2009.

Rizzo, L. V., Correia, A. L., Artaxo, P., Procópio, A. S., and Andreae, M. O.: Spectral dependence of aerosol light absorption over the Amazon Basin, Atmos. Chem. Phys., 11, 8899-8912, doi:10.5194/acp-11-8899-2011, 2011.

Rosencwaig, A.: Photoacoustic spectroscopy, A new tool for investigation of solids, Anal. Chem., 47, 592A-604A, 1975.

Rosenfeld, D., Lohmann, U., Raga, G. B., O’Dowd, C., Kulmala, M., Fuzzi, S., Reissell, A., and Andreae, M. O.: Flood or Drought: How do aerosols affect precipitation?, Science, 321, 1309-1313, doi:10.1126/science.1160606, 2008.

Saleh, R., Robinson, E. S., Tkacik, D. S., Ahern, A. T., Liu, S., Aiken, A. C., Sullivan, R. C., Presto, A. A. Dubey, M. K. Yokelson, R. J., Donahue, N. M., and Robinson, A. L.: Brownness of organics in aerosols from biomass burning linked to their black carbon content, Nat. Geosci., 7, 647-650, 2014.

Sandradewi, J., Prévôt, A. S. H., Szidat, S., Perron, N., Alfarra, M. R., Lanz, V. A., Weingartner, E., and Baltensperger, U.: Using aerosol light absorption measurements for the quantitative determination of wood burning and traffic emission contributions to particulate matter, Environ. Sci. Technol. 42, 3316-3323, 2008a.

Sandradewi, J., Prévôt, A. S. H., Weingartner, E., Schmidhauser, R., Gysel, M., and Baltensperger, U.: A study of wood burning and traffic aerosols in an Alpine valley using a mulit-wavelength aethalometer, Atmos. Environ., 42, 101-112, $2008 \mathrm{~b}$. 
Schmid, O., Artaxo, P., Arnott, W. P., Chand, D., Gatti, L. V., Frank, G. P., Hoffer, A., Schnaiter, M., and Andreae, M. O.: Spectral light absorption by ambient aerosols influenced by biomass burning in the Amazon Basin. I: Comparison and field calibration of absorption measurement techniques, Atmos. Chem. Phys., 6, 3443-3462, doi:10.5194/acp-6-3443-2006, 2006.

Schnaiter, M., Horvath, H., Mohler, O., Naumann, K., Saathoff, H., and Schoeck, O. W.: UV-VIS-NIR spectral optical properties of soot and soot-containing aerosols, J. Aerosol Sci., 34, 14211444, 2003.

Schnaiter, M., Schmid, O., Petzold, A., Fritzsche, L., Klein, K. F., Andreae, M. O., Helas, G., Thielmann, A., Gimmler, M., Möhler, O., Linke, C., and Schurath, U.: Measurement of wavelengthresolved light absorption by aerosols utilizing a UV-VIS Extinction cell, Aerosol Sci. Technol., 39, 249-260, 2005.

Schnaiter, M., Gimmler, M., Llamas, I., Linke, C., Jäger, C., and Mutschke, H.: Strong spectral dependence of light absorption by organic carbon particles formed by propane combustion, Atmos. Chem. Phys., 6, 2981-2990, doi:10.5194/acp-6-2981-2006, 2006.

Snyder, D. C. and Schauer, J. J.: An inter-comparison of two black carbon aerosol instruments and a semi-continuous elemental carbon instrument in the urban environment, Aersol. Sci. Technol., 41, 463-474, 2007.

Sun, H., Biedermann, L., and Bond, T. C.: The color of brown carbon: A model for ultraviolet and visible light absorption by organic carbon aerosol, Geophys. Res. Lett., 34, L17813, doi:10.1029/2007GL029797, 2007.
Thompson, J. E., Hayes, P. L., Jimenez, J. L., Adachi, K., Zhang, X., Liu, J., Weber, R. J., and Buseck, P. R.: Aerosol optical properties at Pasadena, CA during CalNex 2010, Atmos. Environ., 55, 190200, 2012.

Ulrich, E., Beckmann, C., and Israel, G.: The characterization of carbon species in particulate matter by successive thermal desorption, J. Aerosol. Sci, 21, 609-612, 1990.

Voigt, S., Orphal, J., and Burrows, J. P.: The temperature and pressure dependence of the absorption cross-sections of NO2 in the $250-800 \mathrm{~nm}$ region measured by Fourier-transform spectroscopy, J. Photochem. Photobiol. A., 149, 1-7, 2002.

Wagner, R., Linke, E., Naumann, K. H., Schnaiter, M., Vragel, M., Gangl, M., and Horvath, H.: A review of optical measurements at the aerosol and cloud chamber AIDA, J. Quant. Spectrosc. Ra., 110, 930-949, doi:10.1016/j.jqsrt.2009.01.026, 2009.

Watson, J. G., Chow, J. C., and Chen, L.-W. A.: Summary of Organic and Elemental Carbon/Black Carbon Analysis Methods and Intercom-parisons, Aerosol Air Qual. Res., 5, 65-102, 2005.

Weingartner, E., Saathoff, H., Schnaiter, M., Streit, N., Bitnar, B., and Baltensperger, U.: Absorption of light by soot particles: Determination of the absorption coefficient by means of aethalometers, Aerosol Sci., 34, 1445-1463, 2003. 